COMPARISON OF STOPPING DISTANCE, TOWED VEHICLE, AND STATIC METHODS FOR MEASURING SKID RESISTANCE

FEB. 1962
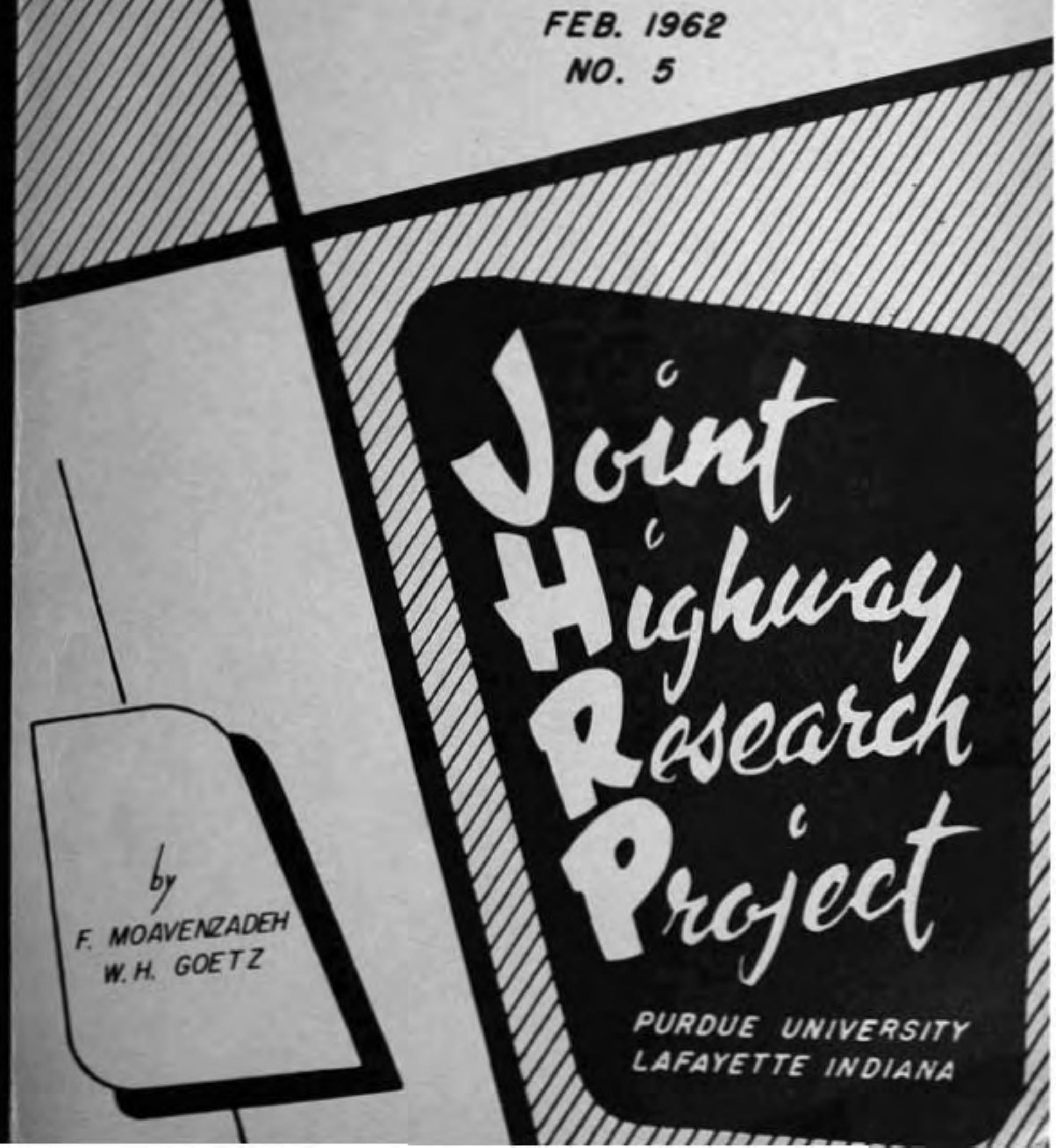
Digitized by the Internet Archive in 2011 with funding from

LYRASIS members and Sloan Foundation; Indiana Department of Transportation 


\section{Rrogress Report}

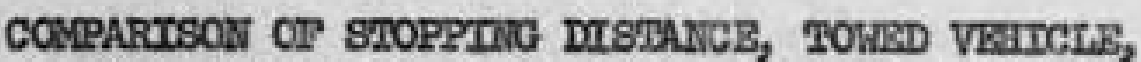

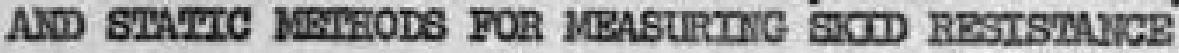

70:

FRON:
K. B. Woode, Darector

Jolnt Highriay Research Project

H. L. Nichael, Associate Director

Joint Highray Research Project
Pebruary 14, 196

F2าe: 9-6-11.

Broject: C-36-53K

The progress report atteched entitiled "Couparlson of Stopping Distance, Towed Vehicle, and Static Nethods for Nessuring Bkid Reststance" hes been suthored. by Fred. Iosvenzadeh and. W. H. Gootz of our staff.

The subject of the report is a research study on the correlation of three methods of measuring the skidaling resistance of highray pavement surfeces. The three methods used vere the slid test vehj.cle, the Rennessee sldi test tratler, and the Hritish portable sldd tester. Iive different sections of pavement vith different anti-skid. characteriatics vere used for the correlation and Included many of the bituminous mixtures which have been placed in recent years in the research concerned with development of mixtures with good enti-skid charecteristics.

the record.

The report is presented to the Boerd as information and for

Reopectrully subentted,

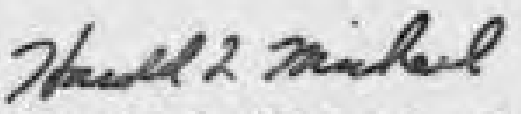

Harold L. Wishael, Secretary

HIM:lanc

Attachment

\section{Copies:}

F. I. Ashbencher

J. R. Cooper

W. I. Dolch

W. \#. Goetz

F. F. Havey

F. S. H11

G. A. Jeonards
J. F. Mcleughiln

R. D. MLles

R. B. Ma17s

M. B. Scott

J. V. Sinthe

J. L. Waring

B. J. Yoder 


\section{Progreas Roport}

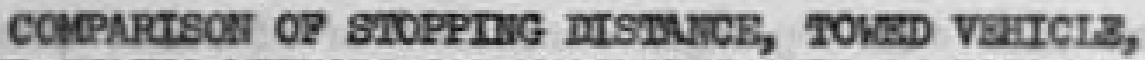
AD BDATIC VEUHODS POR MEASURTIC SICID RISISTAMCE

by

Pred Moavenzadeh

Graduate Assistant

and

V. H. Goetz

Research Bngineer

Joint Highray Research Project

File No: 9-6-12

Project Nlo: C-36-53K

Purdune University

Lafayette, Indiann

Pebruary 14, 1962 


\section{Introduction}

One of the anjor problems currentiy confronting the highneg enginoer in many areae is to conetruet highrays that will exhibit satiafaetory ant1-aldd charactarigtica for a roascnable length of tIso. All pevement surfaces can develop adequate diddding resiatance in a dry state but aeny of thee may be oritically allppory when vet.

The mafority of the highisyse congtrueted recently have posseseed adequnte wot siddding resilstance ihon new. Unfortunately, co vany of theee surfaces this initial anti-aldid realotanes has been ehost1fred. As a result, it has becone inereasingly inportant to give sons consideration to the change in sicldding rosiotanes of peveanat surfaces due to the pollahing effects of traffie.

Das to the endlese 21 st of variables, including factors portaining to the ageregato, the binder, traffie and age, neascnal varlables, and the condition of the surfece during testing, the moot appropilate moans of teating io fleld Investigation.

At prosent many machines ere being used for rating the alfpporiness of pavemont surfaces, and most of then are sorving their intendod purpose quite wall afnce Individual agenoles can mike sound Judignents on the baslo of relntiv road alipperiness values obtalned with their machines. But the exchange of data amcng theae agoneles is very diffleult, and the need for s atendard method is very obvious. Any attenpt toond selection of a standard method mast be preceded by a corralation botween the exdoting sethod and andysis of the variables that they asasuro. lang the moet prosiofing daviees are:

1. Stopping distance methed

2. Towod vehiole techniqua, and

3. Statle machinee 
In wumer 1961, the bituminous leboratory used three pleces of oquifment to mesour the did characterietics of sevoral bituninous ourfaces. For this purpose the folloding oquiposnt was utllesed:

1. The stopping distanee car of the Indiana State Hehnay Departaent

2. A tarod-vahiole mahine Idontirfied as the Fonnessee Sidd Tost Fradler tron Onifroralty of Tannesece, and

3. A British Portable Sldid Tester oroed by Purdue thivaroity. Areas Fosted

The alteo whlah wore solected for this study included flve differvat arses vith contrssting anti-aldd cheracteristies.

Ares I inoluded 24 oxperinatal sections of sand aix lasid in 1959 on the south-bound lenes of U. S. 52 north of the Junetion with S.R. 28. The thickness of the layer was about one-hale 1noh and the coraposition of the $m i x$ can be seen in Table $I$.

Aree II Included 8 experimentel sectlons of fine eand mix and a seoticn of the ald pevement. The 8 sections of the sand mix vere lasd during the surmar of 1960 on the south-bound lenes of U. 8.52 north of Konroe. Tholr ecaposition is presented in Table $I$.

Arve III Ineluded a section of S,R, 28 east of the junetion with $0 . S, 52$. This section of S.R. 28 is surfaced with Kentuolg Rock Asphelt.

Aroa IV Inoluded a four wlo stretch of graval bitundnous conerete vith approdintely $60 \$$ coeree aggregato and $40 \% \mathrm{KIne}$ sggregate an the north-bound Innes of U. S. 52 fron four to ef ght mles south of Iafayette.

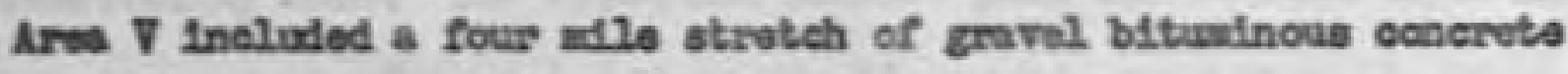
idth approudately 458 coerse aggregate and 558 fine aggregate an the nosth-bound lanes of V. S. 52 fron Iafayette to four alles south. 


\section{Bquifpont Deed}

sidd rost Cnr

Tho sld toot car weo a 1956 Ford with vacuis-operated brakas. Tho coly additionel equifpent on thils car vas a speedoneter which rocorde the opeed whon the brakes are applied and an odonoter attached to a firth wool. Tho oar was braked at a speed olose to $30 \mathrm{mph}$ and tho eleldding distance for that epeod ves neesurod. A chart vas arallable to earrect this diftance to 30 eph apeod.

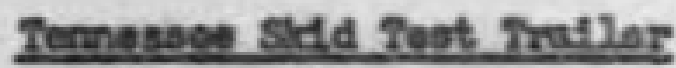

The sidd tratler consisted of a $4 \times 6 \mathrm{rt}$. ecnervte slab mounted on the aodifled frout-axle asseably of a paseanger car. The slab provides a velght of approxinately 835 Iba. on the teat wheel. The tratlor 10 ecnneoted to the toir truek by an off-net drawber which is In direct alfgrment whth the center of the loft or inodide trailer wheol. Through a otraln-gauge mechanism any pull exortod on the drawbar caused foree to be indicated on a brush rocordor through an analyser. The teot trailor was pulled by a two-tan Chevrolot truck whlch 1o oquippod with a 500 gallon vater tank and a oprinkaling bar so that a stross of vater is dirocted at ths pavenent about $2 \mathrm{ft}$. In front of the sicldating whel. The operation of the mashine is fully autcant10 00 that cace the centrol button is puahed and the eutcosatis oyoling mochanisn is energized, the vator valvo is opened, and one and coe-hale seoonde later the brake is autcosticelly appled on the traller and it held for alfghtly under two soconds. Throe wuch tosts are eutcoticelly made. The apeed and drevibar poll can be read diroctily fron the groph of the 3rush recorder. Traller teats wero made at speods of $10,20,30$, and 40 aph in tast caees, and at 50 mph in a ferr cenos. 


\section{Bertitsh Portable sicld Teater}

The British Portable Skdd Teater is a device developed in the Road Research Laboratory in Great Britain. It is a pondulum type of machine, in which a slider three-Inches long and one-inch wide takes the place of a slcldiling tire. The mechine ean be adjusted vertically so that the length of surface that the allder traverses can be centralled. Aftor the proper adfuatmente are made, the pandulum and a pointer, which aets from the samse axdis as the pendulum, ars cocked in a horizontal posittion. Upon relasse, the pendulum carries the pointer through an are and falls avay, leeving the pointer at the furthest point of the are travarsed by the pendulum. At this point, a messurement is recorded from a diract seale. The scale is calibrated diroctily, the readinge given being 100 times the effective coefficient of Irletion as deduced by equating the work done againat friction by the alider to the loss in onergy of the pendulum arm. Coneiderable attention has been given to ensuring that the apparstus vill be quick and eew to use on the rad. The rubber alider is froe to tilt gideways to follow isregularities of the surface and is loaded by an arrangement giving a very low spring rate so that the normal load on the surfece stays substantiany constant throughout the swing even on very rough surfaces. Bucperimantal Dasten

The experiment was designed to provide a poselbilitity of correlation of the three mothods of aldid teating. For this purpose, at first the treller tester was used in all IIv areas st different apeeds. At ares I and II, the trailer measured the coepficient of friction of each aection for both driving lane and passing lane at different speeds and in direotion of traffic and opposite the direction of traefle, 


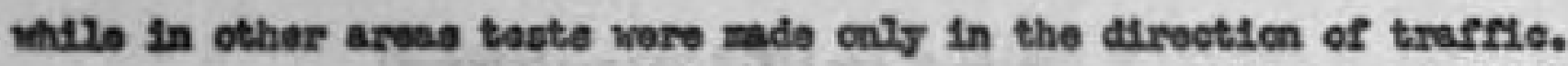
After the carplotson of teats with the trasler, the sldd car nas uaed for the was socticns with the same diroetsans. Finslly the Portable Sidd Tester wo weod in mariked arvas where the tost car had siddded. For each otrlp on which the car had elcldded three poolticns wore tested, two onds and middle, and at each posttion ten rastings were taken. The readings which varled more than 3 points vore discarded. At each position the terporsture of pavanent iss rocordod. To elininate the effect of tenporature on the rosults of Portablo Sldd Toster, all the values of coefriefent of frietion obtained by this device wore corrected acoording to a mothod deacribed in Appendix A. 
Table 1

\section{Description of Sections Tested}

Area I. 127 Sand Seations - U, S. $52 \mathrm{~N}$ of $S_{0} R_{0} 28$

Conposition (Design)

\begin{tabular}{|c|c|c|c|c|}
\hline $\mathrm{Sec} . \mathrm{NO}_{3}$ & $\begin{array}{r}\text { III7 } \\
\text { Sand } \\
\end{array}$ & $\begin{array}{l}\text { Mineral } \\
\text { piner }\end{array}$ & Aaphalt & $\begin{array}{l}\text { Percent } \\
\text { Asphalt }\end{array}$ \\
\hline $\begin{array}{l}2 \\
2 \\
3 \\
4 \\
5 \\
6 \\
7 \\
8 \\
9 \\
10 \\
11 \\
12 \\
13 \\
13 \\
15 \\
11 \\
17 \\
18 \\
19 \\
20 \\
22 \\
22 \\
23\end{array}$ & $\begin{array}{r}100 \\
100 \\
100 \\
100 \\
100 \\
95 \\
95 \\
95 \\
95 \\
95 \\
100 \\
100 \\
100 \\
100 \\
100 \\
95 \\
95 \\
95 \\
95 \\
95 \\
90 \\
100 \\
100\end{array}$ & $\begin{array}{r}0 \\
0 \\
0 \\
0 \\
0 \\
5 \\
5 \\
5 \\
5 \\
5 \\
0 \\
0 \\
0 \\
0 \\
0 \\
0 \\
0 \\
0 \\
0 \\
0 \\
10 \\
0 \\
0\end{array}$ & $\begin{array}{l}A B-60 \\
A B-60 \\
A B-60 \\
A B-60 \\
A B-60 \\
A B-60 \\
A B-60 \\
A B=60 \\
A B-60 \\
A E-60 \\
A B-90 \\
A B=90 \\
A B-90 \\
A B=90 \\
A B-90 \\
A B-90 \\
A B-90 \\
A E-90 \\
A E-90 \\
A B-90 \\
A B=90 \\
A B=150 \\
A B-200\end{array}$ & $\begin{array}{l}6.5 \\
7.0 \\
7.5 \\
8.0 \\
8.5 \\
6.5 \\
7.0 \\
7.5 \\
8.0 \\
8.5 \\
6.5 \\
7.0 \\
7.5 \\
8.0 \\
8.5 \\
6.5 \\
7.0 \\
7.5 \\
8.0 \\
8.5 \\
8.5 \\
7.5 \\
7.5\end{array}$ \\
\hline
\end{tabular}


Table 2 (Continued)

Aroa II. Fine Sand Sections - U. 3. 52 II of Monroe

$$
\text { Conposition }-x \text { (Dasign) }
$$

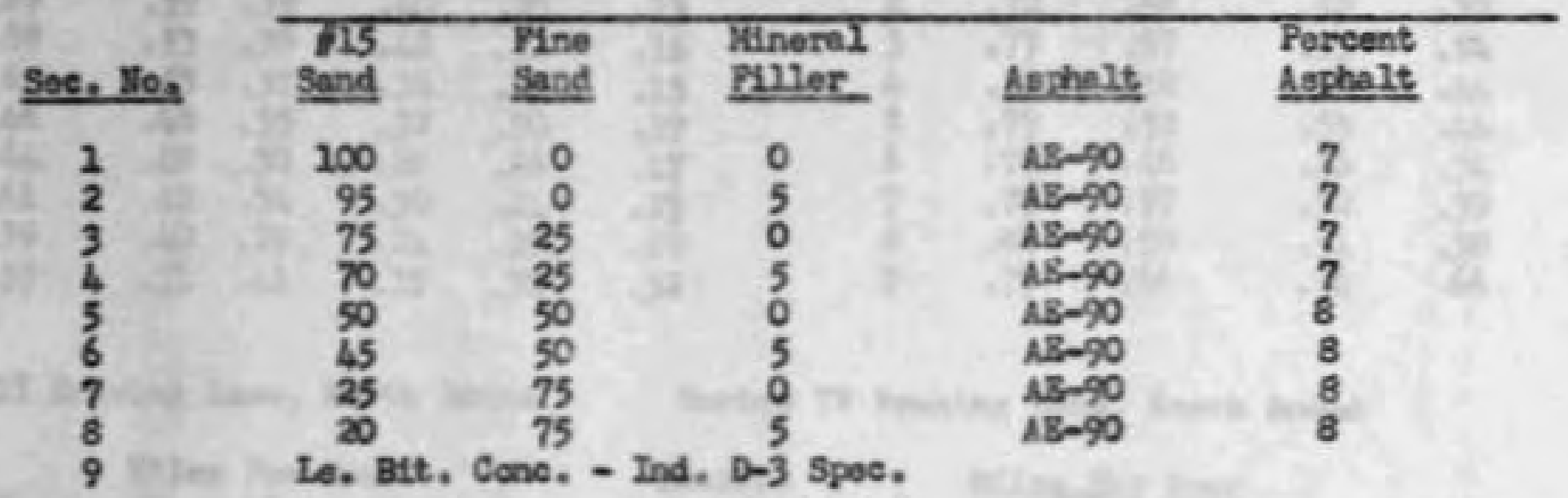

Ave III. Rock Agphalt. 3, R, 28 east of function vith U, S, 52

Ratural Erock

Grevel Bit. Conc. = Ind. Deb Spacen U.S. 52 - N.B. Iane

Area IV. $8 \mathrm{mil}$ south of Iafayetta -

60 s 121 groval-Wos $/ 17$ and

Arse 7. 4 al. south of la fayotte -

$40 \%$ RI gravel-60\% 27 and 
$-8-$

Tablo 2

Tornesaso Sidd Tent Trasler Results

ARsa I

Fino Send

Sorles I Driving Lene, South Bound Section

\begin{tabular}{|c|c|c|c|c|c|}
\hline 10 & 20 & $\sin 1$ & $\cos 2$ & 40 & \\
\hline .68 & .66 & .62 & 4.48 & .47 & 2 \\
\hline & .59 & .39 & .40 & .27 & .2 \\
\hline $6 \%$ & .53 & .39 & $=42$ & .92 & \\
\hline 6 & .53 & -37 & .34 & 25 & \\
\hline & .48 & -35 & .32 & +30 & \\
\hline & .42 & 34 & 30 & 21. & \\
\hline & .160 & .29 & 24 & .26 & \\
\hline & .52 & .42 & .38 & .38 & \\
\hline
\end{tabular}

Serles II" Fassing Iane, South Bound Section

\begin{tabular}{lllll} 
& 10 & \multicolumn{2}{c}{30} & \\
1 & .76 & .64 & .5212 & 40 \\
2 & .72 & .58 & .59 & .58 \\
3 & .77 & .57 & .52 & .37 \\
4 & .76 & .55 & .55 & .54 \\
5 & .79 & .52 & .55 & .44 \\
6 & .77 & .52 & .55 & .44 \\
7 & .79 & .56 & .46 & .34 \\
8 & .82 & .57 & .52 & .39 \\
9 & .79 & .50 & .51 & .38 \\
9 & .66 & .74 & .66
\end{tabular}

aries III Driving Lane, North Bound lection $10 \quad 20 \quad 30 \quad 50$ $\begin{array}{llll}.63 & .57 & .48 & .34\end{array}$

$\begin{array}{llll}.57 & .48 & .38 & .16\end{array}$

$\begin{array}{llll}.60 & .45 & .32 & .16\end{array}$

$\begin{array}{llll}.57 & .43 & .30 & .17\end{array}$

$\begin{array}{llll}.63 & .44 & -32 & .21\end{array}$

$\begin{array}{llll}.57 & .45 & .28 & .22\end{array}$

$.53 \quad 46 \quad 31 \quad .24$

$\begin{array}{llll}.57 & .40 & .25 & -24\end{array}$

$\begin{array}{llll}.45 & .37 & .36 & .52\end{array}$
Serries If Pasesing Lane, North Bound

Sootion

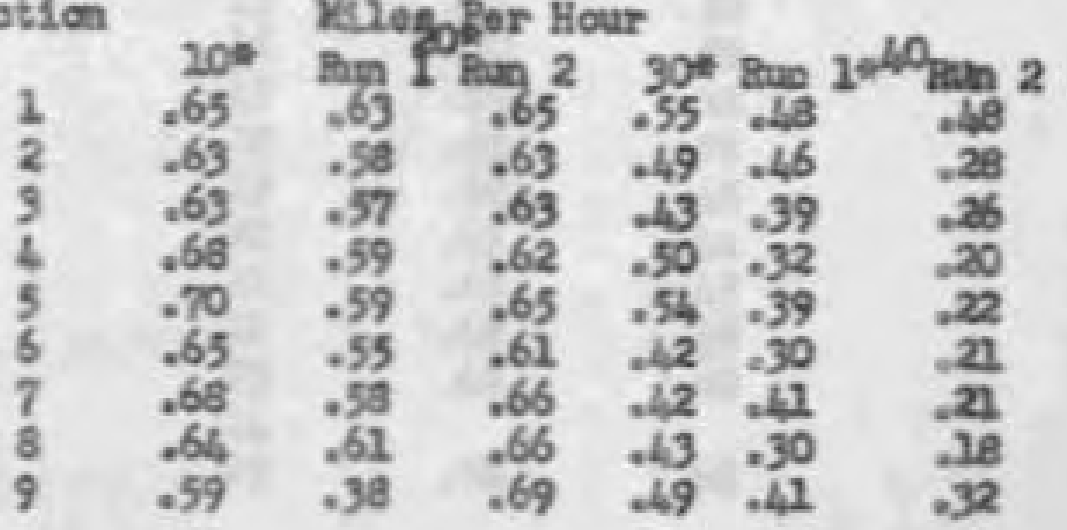

C-16-50

Ban No 1 0 30 aph In Sorlos II was rerun as wator was low

Run No 1040 mph in Sorlos IV vas rerun at a Lifferent chart multiplefer seale 
Tabla 2 (Contsnued)

Ho. 17 Sand

Serles I Driring Iano, South Bound

Section 10

\section{yilas Per How}

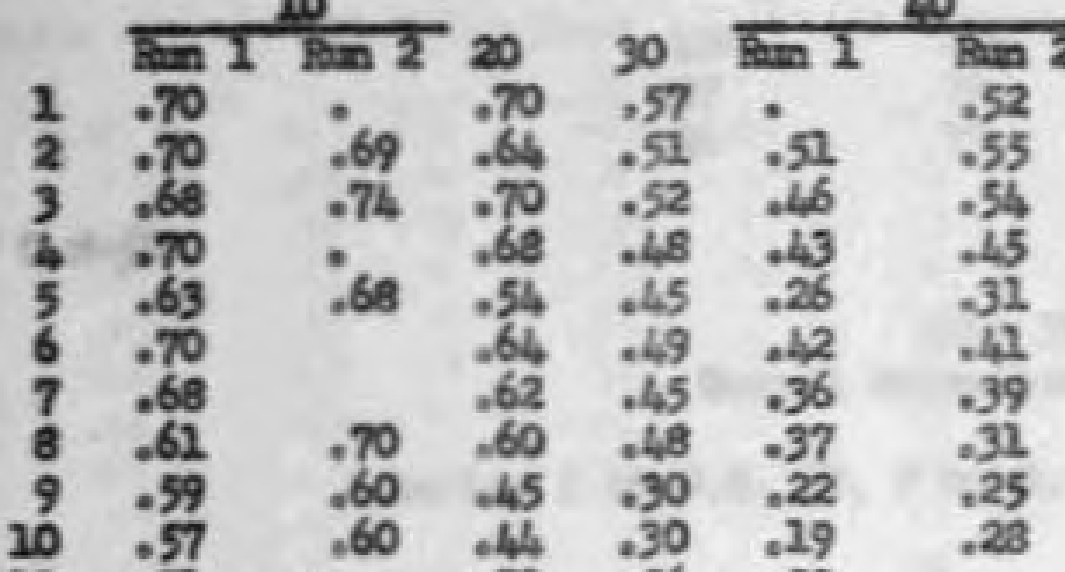

11.72

2

13.70

น. .69

15.73

16.69

17.68

$18 \quad .66$

19.61

20.49

21.56

$22 \quad .68$

23.68

24

$25 \quad .66$

$.70 \quad .56 \quad .59$

$\begin{array}{lll}.74 & .62 & .59\end{array}$

$.68 \quad .59 \quad .49$

$\begin{array}{llll}.74 & .64 & .53 & .46\end{array}$

$\begin{array}{llll}.69 & .54 & .50\end{array}$

$\begin{array}{llll}.74 & .64 & .60 & .48\end{array}$

.62 .48 .48

$\begin{array}{llll}.69 & .53 & .47 & .37\end{array}$

$\begin{array}{llll}.66 & .48 & .36 & .25\end{array}$

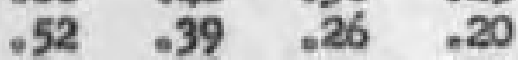

$\begin{array}{llll}.60 & .36 & .23 & .22\end{array}$

$\begin{array}{llll}.70 & .55 & .34 & .34\end{array}$

$.72 .52, .39 \quad .42$

$\begin{array}{llll}.68 & .51 & .52 & .45\end{array}$
Serteas II Pasaing Lene, South Bound

Soction valos Per Hoor

$\begin{array}{lll} & 20 * & 30 \\ 1 & .72 & .65 \\ 2 & .70 & .60 \\ 3 & .70 & .60 \\ 4 & .70 & .62 \\ 5 & .73 & .58 \\ 6 & .68 & .59 \\ 7 & .70 & .58 \\ 8 & .68 & .58 \\ 9 & .68 & .58 \\ 10 & .69 & .59 \\ 11 & .72 & .57 \\ 12 & .74 & .57 \\ 13 & .72 & .60 \\ 14 & .68 & .58 \\ 15 & .73 & .58 \\ 16 & .70 & .59 \\ 17 & .69 & .64 \\ 18 & .65 & .59 \\ 19 & .68 & .45 \\ 20 & .63 & .44 \\ 21 & .63 & .47 \\ 22 & .68 & .58 \\ 23 & .68 & .60 \\ 21 & .68 \\ 25 & .76 & .68\end{array}$

$* 0-4-50$

Notor Brake was operuting Inproperly in severnl of these runs. 
$-10=$

Table 2 (Continued)

APIBA III

Kentuclog Roek

Series I Bast of U.S. 52, Driding Lenes

TEST mo.

$\frac{1}{2}$

$0-2-50$
ICUES FER HOUR, Funinic TESIS

$10 \%$
.87
.86
Aley fres U.S. 52

.62

\section{.74}

Tevard U.S. 52

30 is

$.67 \quad .58$

\section{AREA IV}

Gravel attudnous Conervte

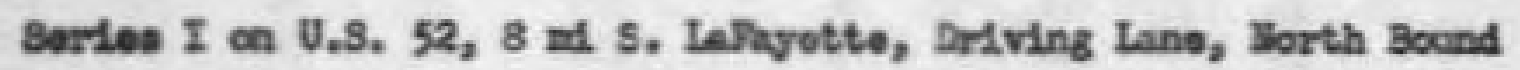

TSSE w0.

$\frac{2}{2}$

1CH Standard Test

$\begin{array}{llll}10 & 20 & 30 & 40 \\ .58 & .42 & .28 & .22 \\ .56 & .40 & .28 & .23\end{array}$

Test lio.

1
2
3
4
5
6
7
8
Yeles Per Hour, Fanning Test 30 .32 .34 .38 .31 .35 .31 .34

\section{AREA V}

Grovel Bttuminous Conerote

Sorles I, an U.S. 52, 4 and S. IaFayotte, Driving lane, Wlorth Bound

Trss? mo.

$\frac{1}{2}$
MPF Standard Test $\begin{array}{llll}10 & 20 & 30 & 40\end{array}$ $.63 .51 \quad .34 \quad .25$ .64 .45 .40 .30
Tost Ilo.

2
2
3
4
5
6
7
8
9
10
Males Per Hour, Bunning Test 30 .34 .37 .30 .34 .35 


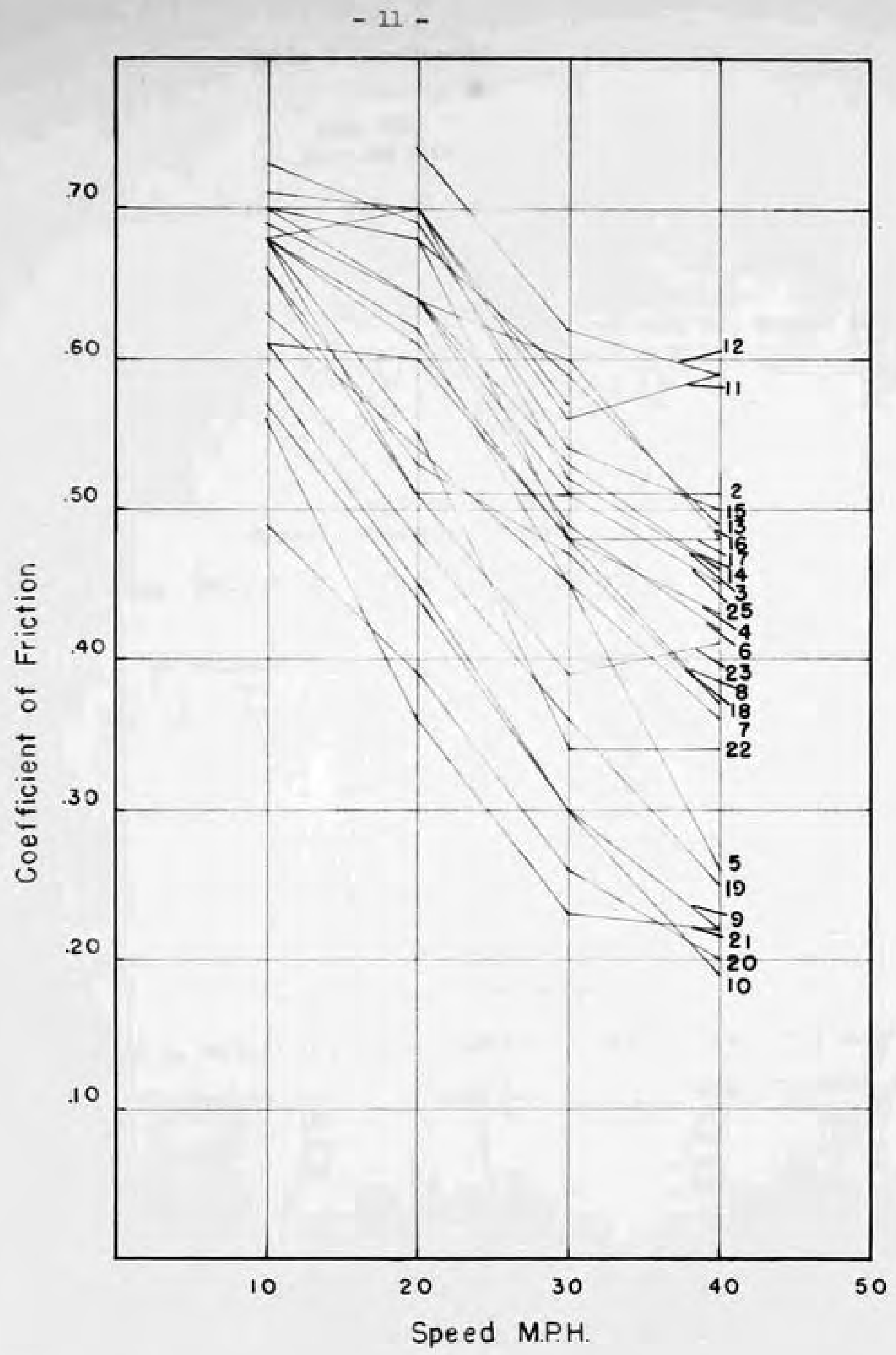

Fig. I

AREA I

No 17. Sond

Series I Driving Lane. South.Bound 


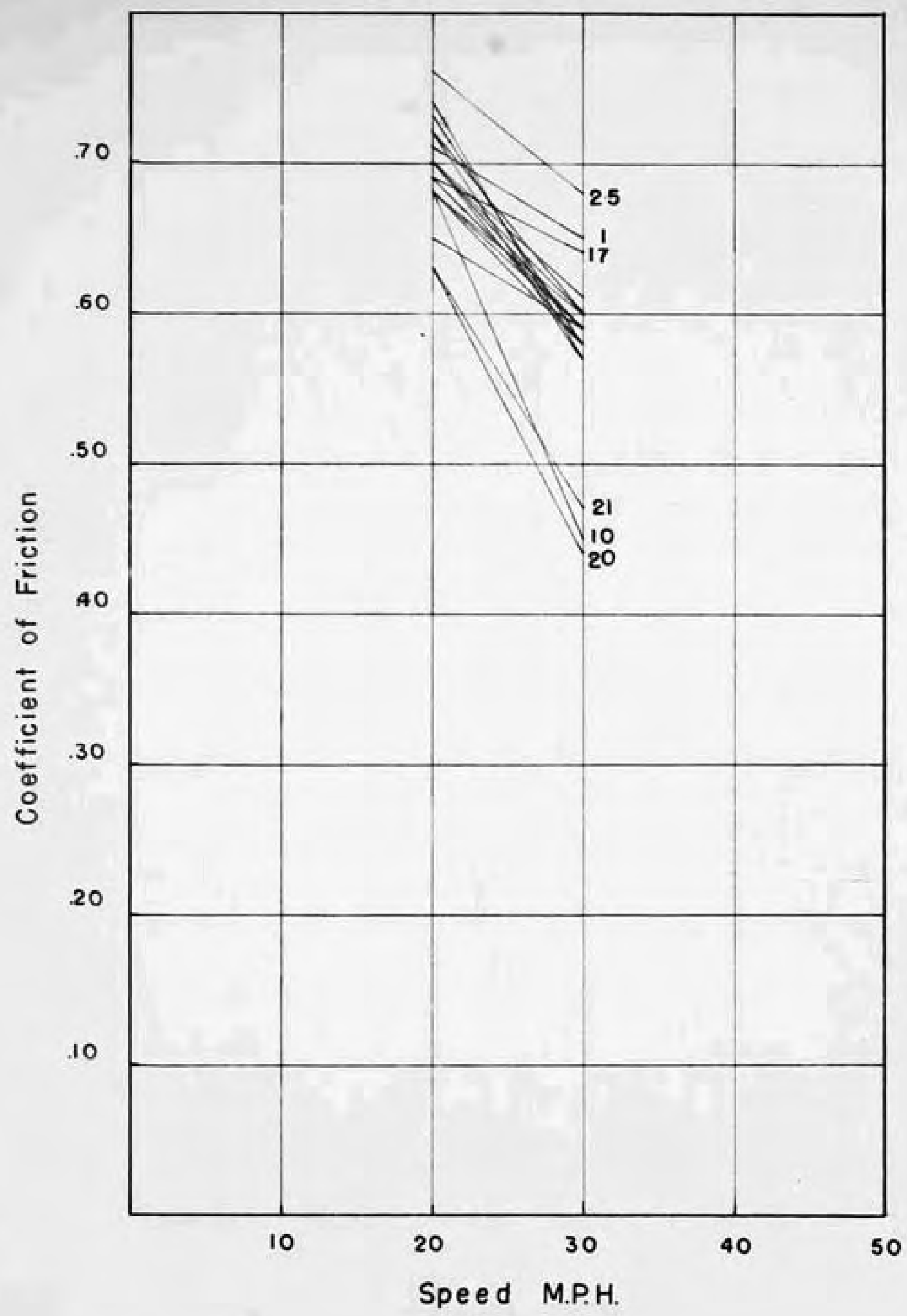

Fig. 2

AREA I

No 17. Sand

Series II Passing Lane South Bound 


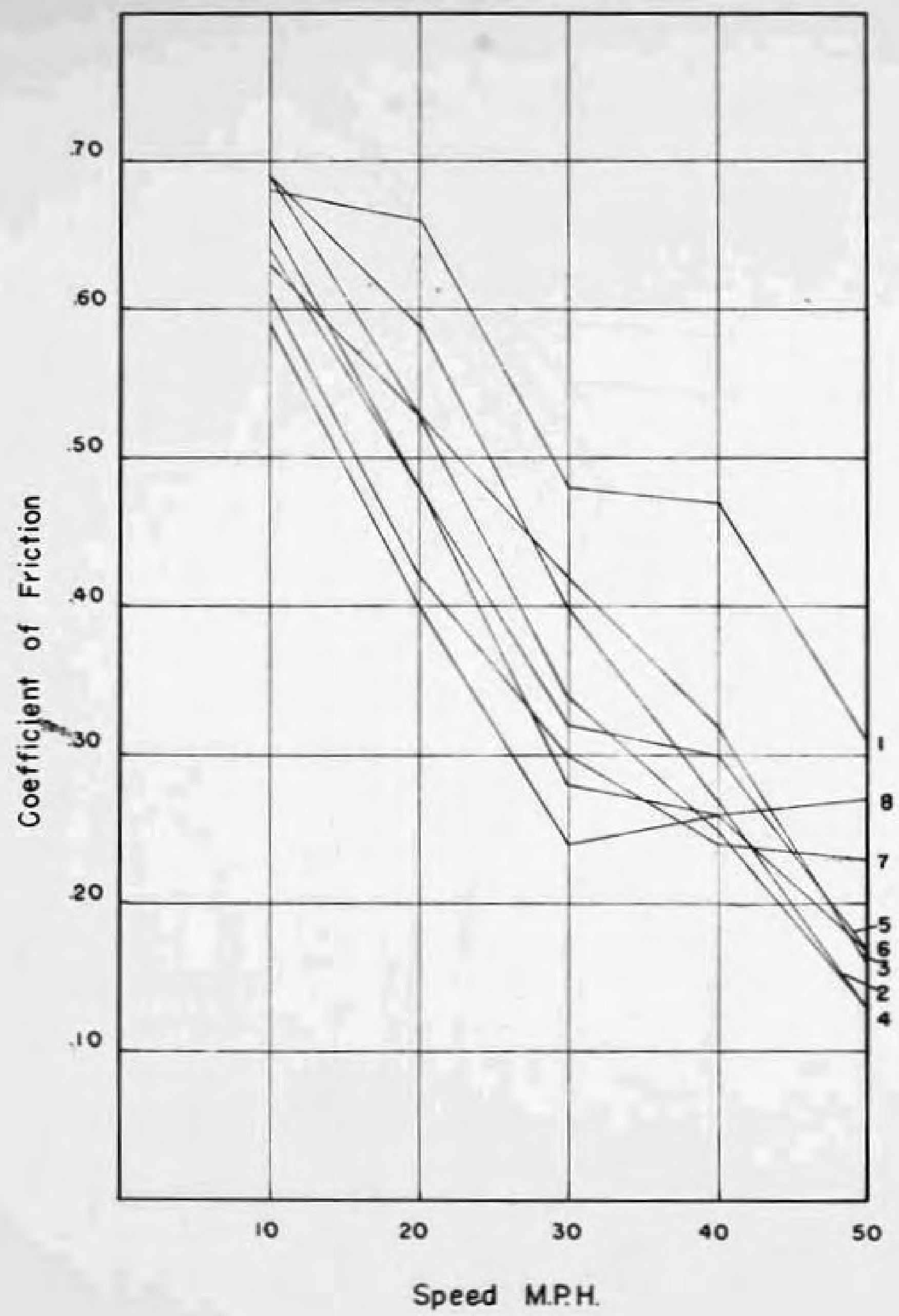

Fig. 3

AREA II

Fine Sand

Series I Driving Lane South Bound 


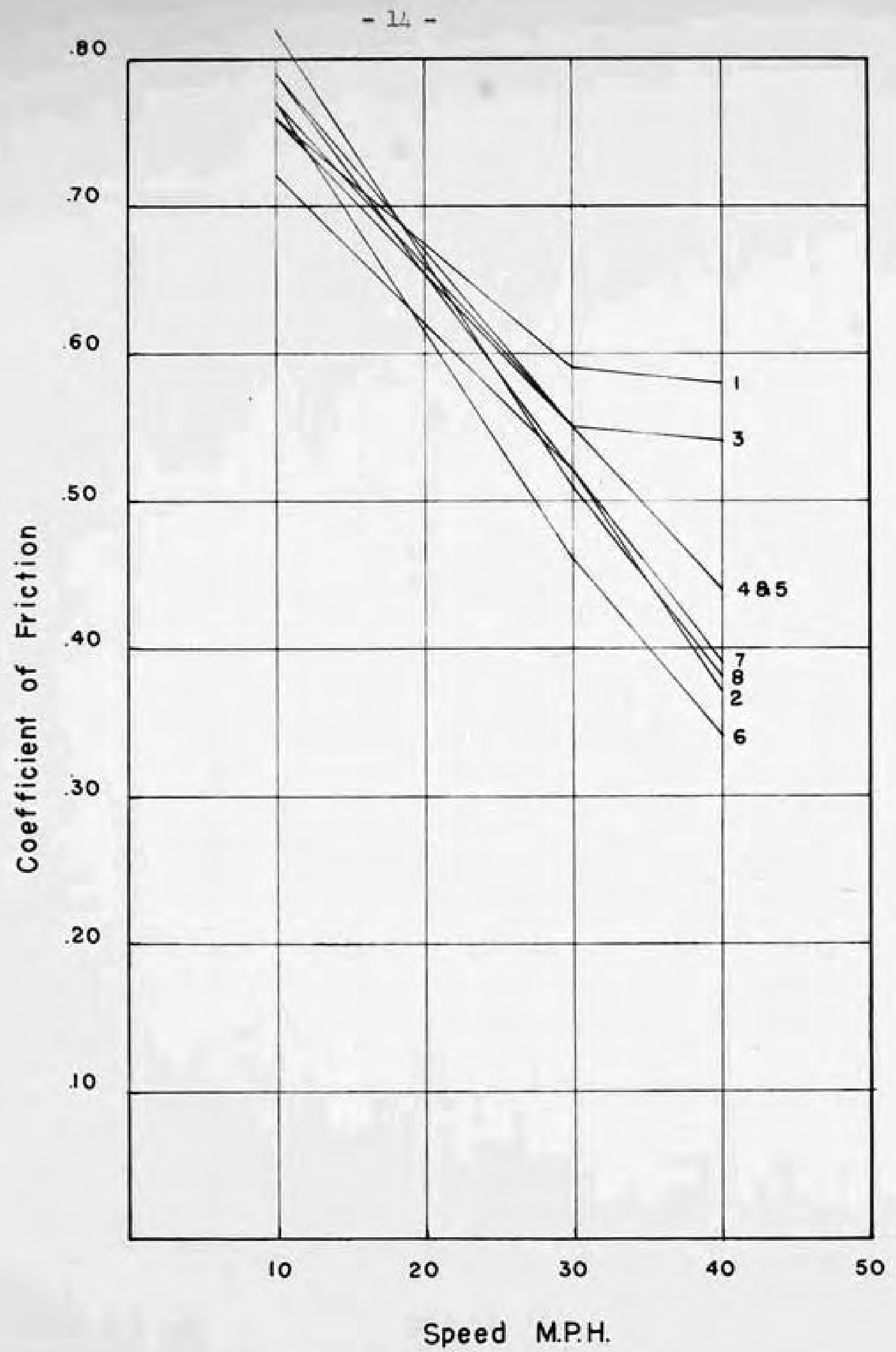

Fig. 4

AREA II

Fine Sand

Series II Passing Lane South Bound 


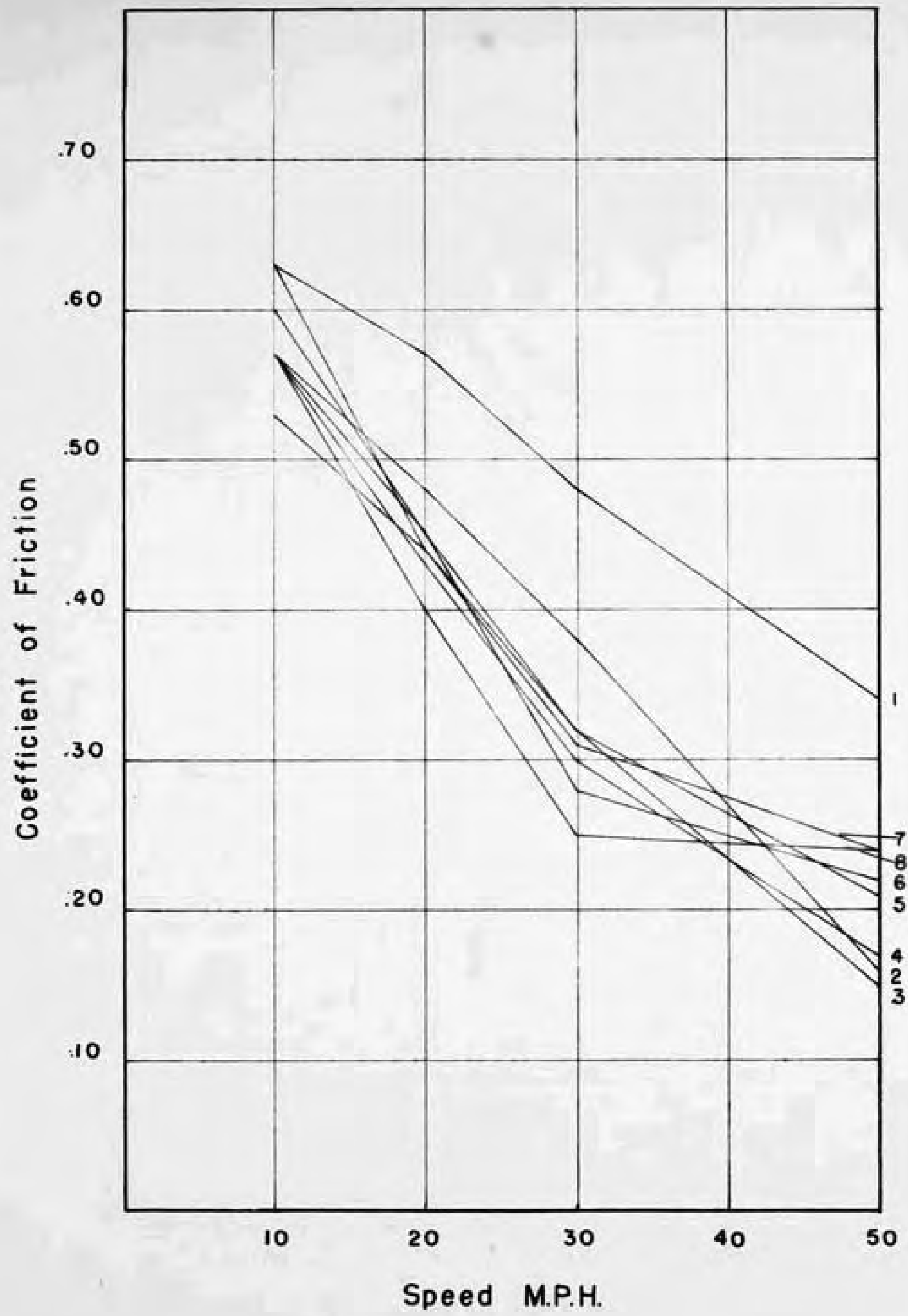

Fig. 5 .

AREA II

Fine Sand

Series III Driving Lane North Bound 


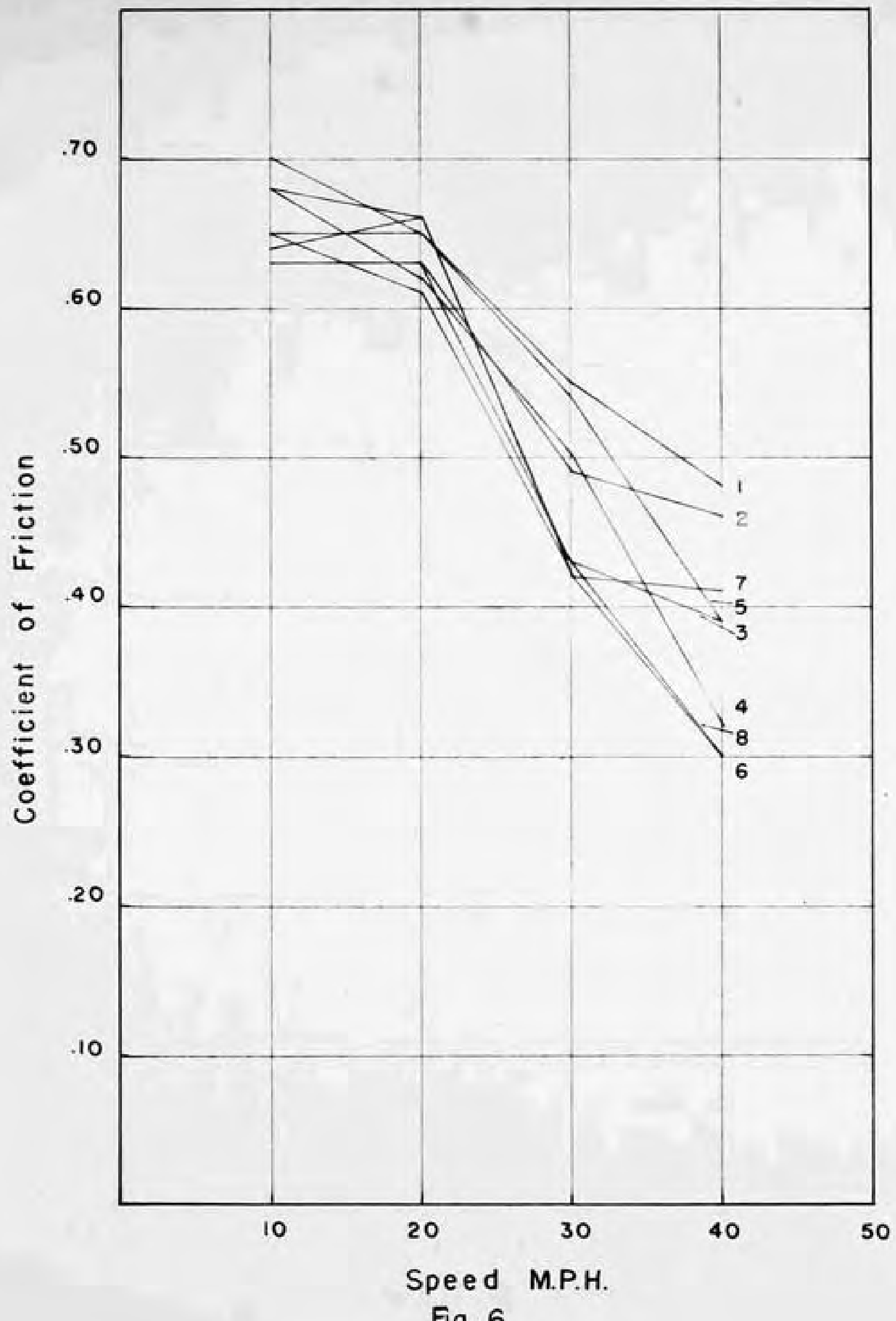

Fig. 6

AREA II

Fine Sand

Series IV Passing Lane North Bound 


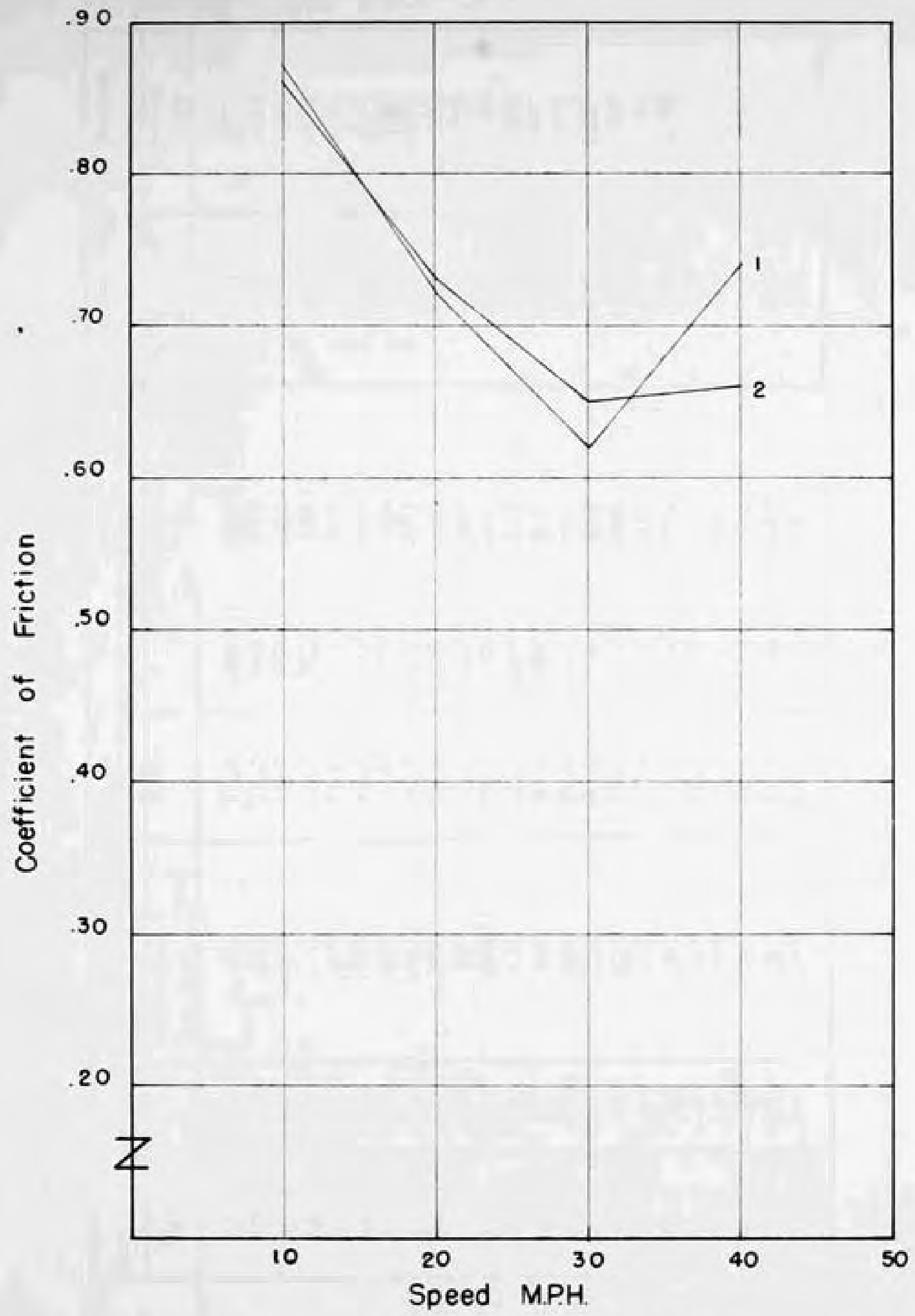

AREA III (SR-28)

Kentucky Rockasphalt

Series I East Bound Lane

Fig. 7 


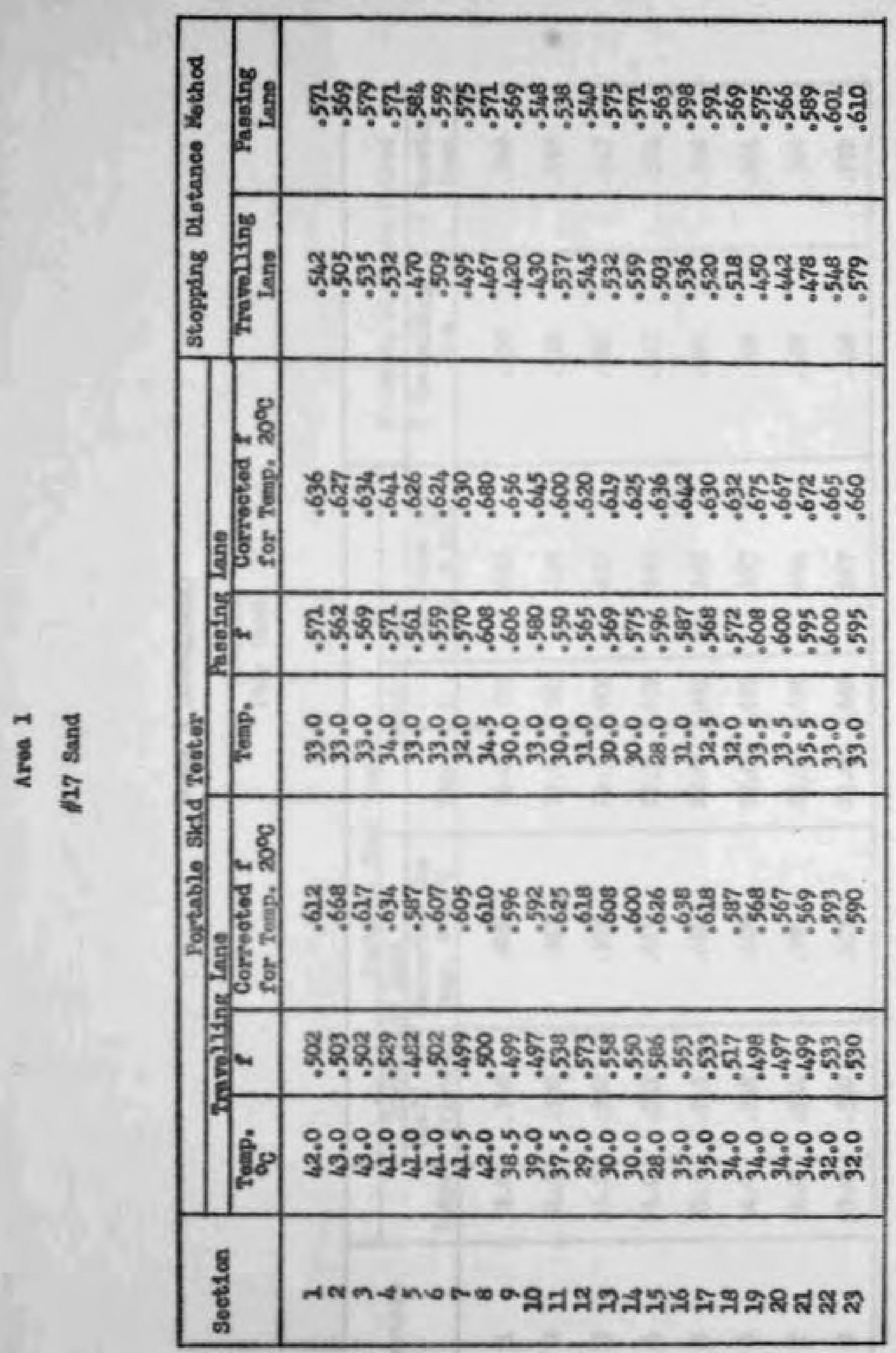



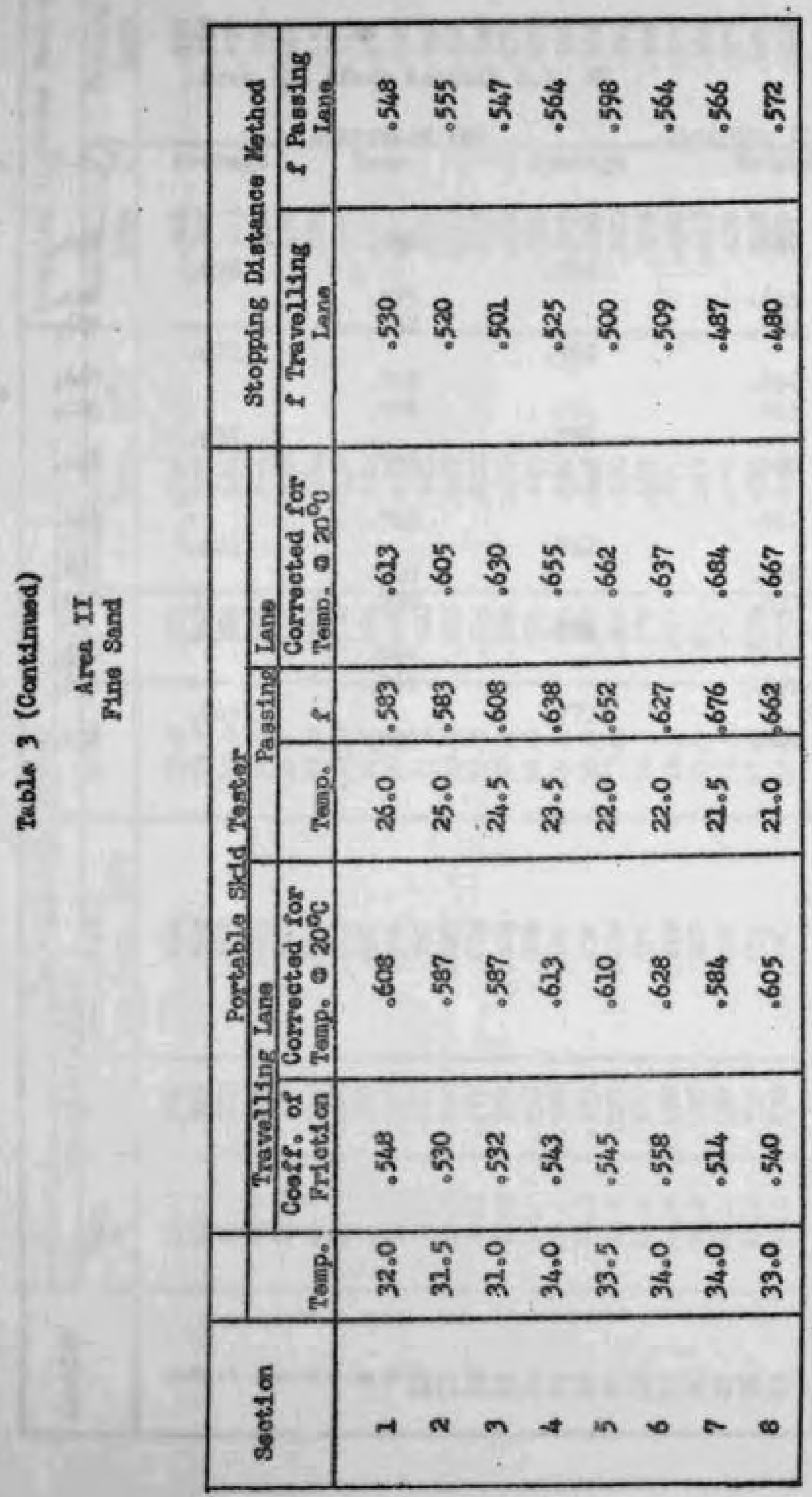
Tablo 3 (Continued)

Ares III Rock Aophalt S.R. 28

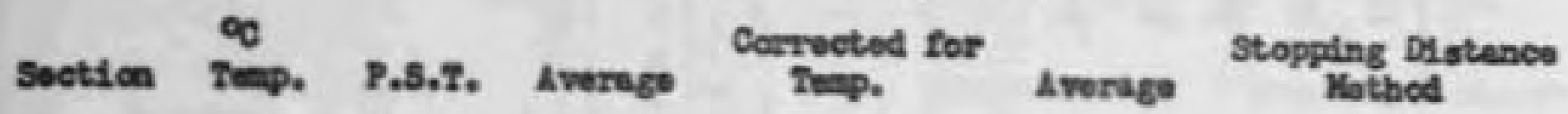
Best Bound
$\begin{array}{llll}\text { u } & 37.5 & .669 \\ 18 & 37.5 & .688 \\ 24 & 37.0 & .67\end{array}$

$.678 \quad .756$
.775
.758
.765
.630
2
2839.5 .669
$34 \quad 40.3^{\circ} .62 \%$
.67
.762
.766
.635
.726
$38 \quad 42.5 \quad .665$
.776
.75
.645
.625
.632
.645
.620
$14 \quad 4.5 \quad .646$
1 18 $43.0 \quad .623$
$21 \quad 38.5 \quad .649$
2
$23 \quad 41.0 \quad .653$
$34 \quad 42.0 \quad .652$
3
$38 \quad 42.0 \quad .676$

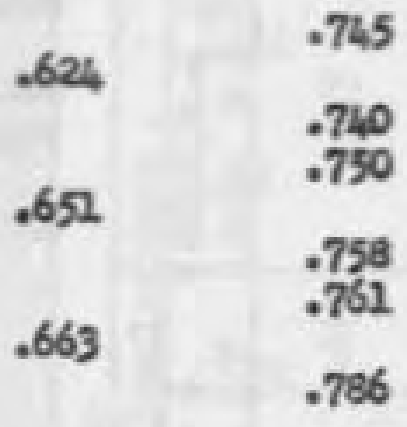
.742
.640
.620
.632
.754
.623
.652
.773
.622

Averege 
$-23$.

Table 3 (Continued)

Area IV

Grsvel Bituninous Conorvte

U.S. 52 - North Bound Lano

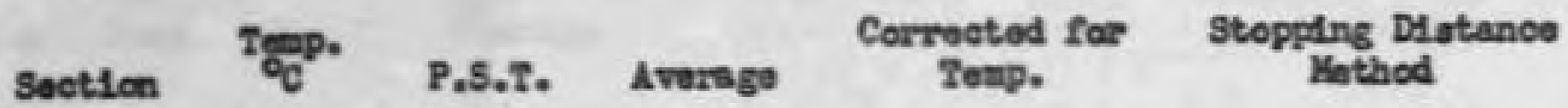

Irav. Iano

$2 \quad \begin{array}{lll}37.5 & .458\end{array}$

$18 \quad 38.5 .443$

.450

.540

.390

21. 37.5

.438

.445

.520

.376

$2 B \quad 37.0 \quad .452$

Paes, Iano

21 $38.5 \quad 499$

1

18 $38.7 \quad .636$

21 $39.2,451$

2

2B $39.5 \quad 449$

.492

.585

.494

.4 .50

.5142

.470

Area V

Grave 3 Bituminous Conerete

U.S, 52, North Bound Lano

Soction Tomp. P,S,T. Average $\begin{gathered}\text { Correoted for } \\ \text { Temp. }\end{gathered} \begin{gathered}\text { Stupping Distance } \\ \text { Method }\end{gathered}$

Trev. Lane

$\begin{array}{lll}14 & 36.2 \quad .478\end{array}$

$\begin{array}{llll}1 & 18 & 37.7 & .456\end{array}$

.467

.552

.465

22138.3

.507

.507

.597

.478

11 $\quad 37.5 \quad .499$

2

$\begin{array}{lll}23 & 38.0 \quad .502\end{array}$

.502

.590

.494

2

$\begin{array}{lll}21 & 38.2 \quad .525\end{array}$

$23 \quad 38.2 \quad .495$

.510

.600

.487 


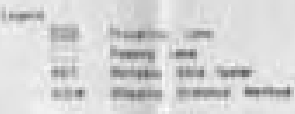

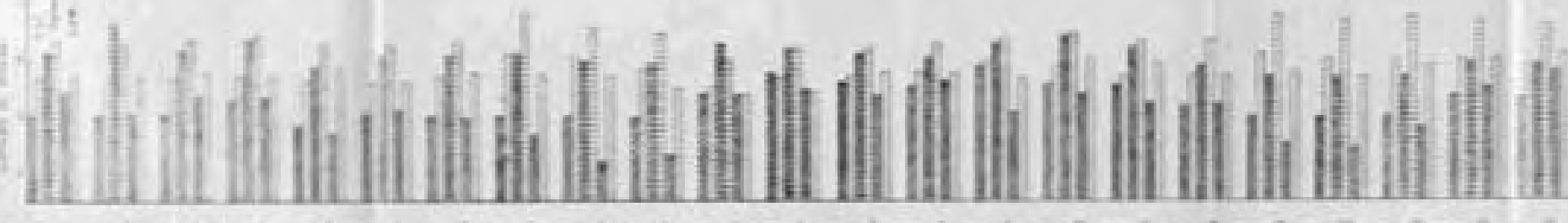

- 프.

tan 


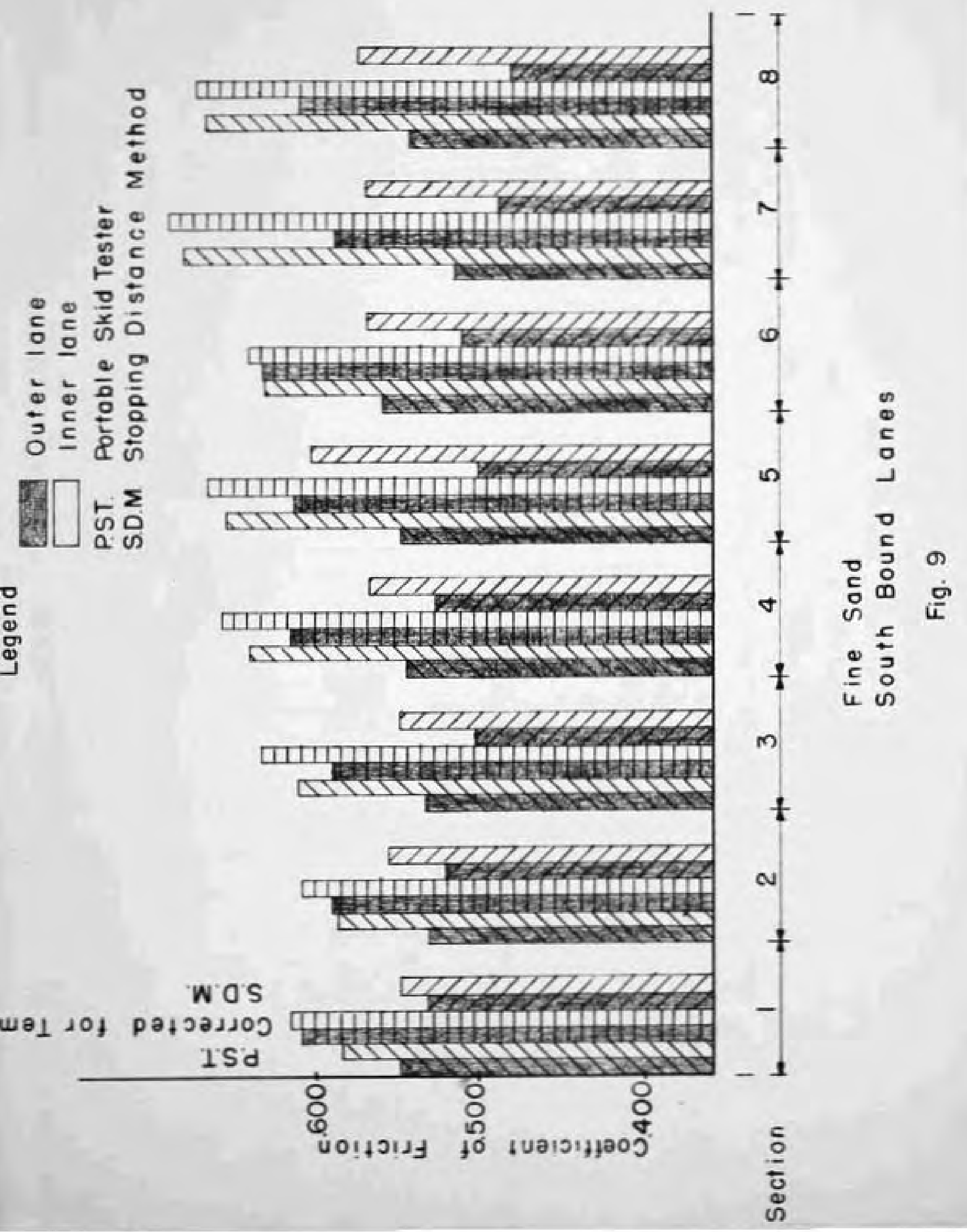




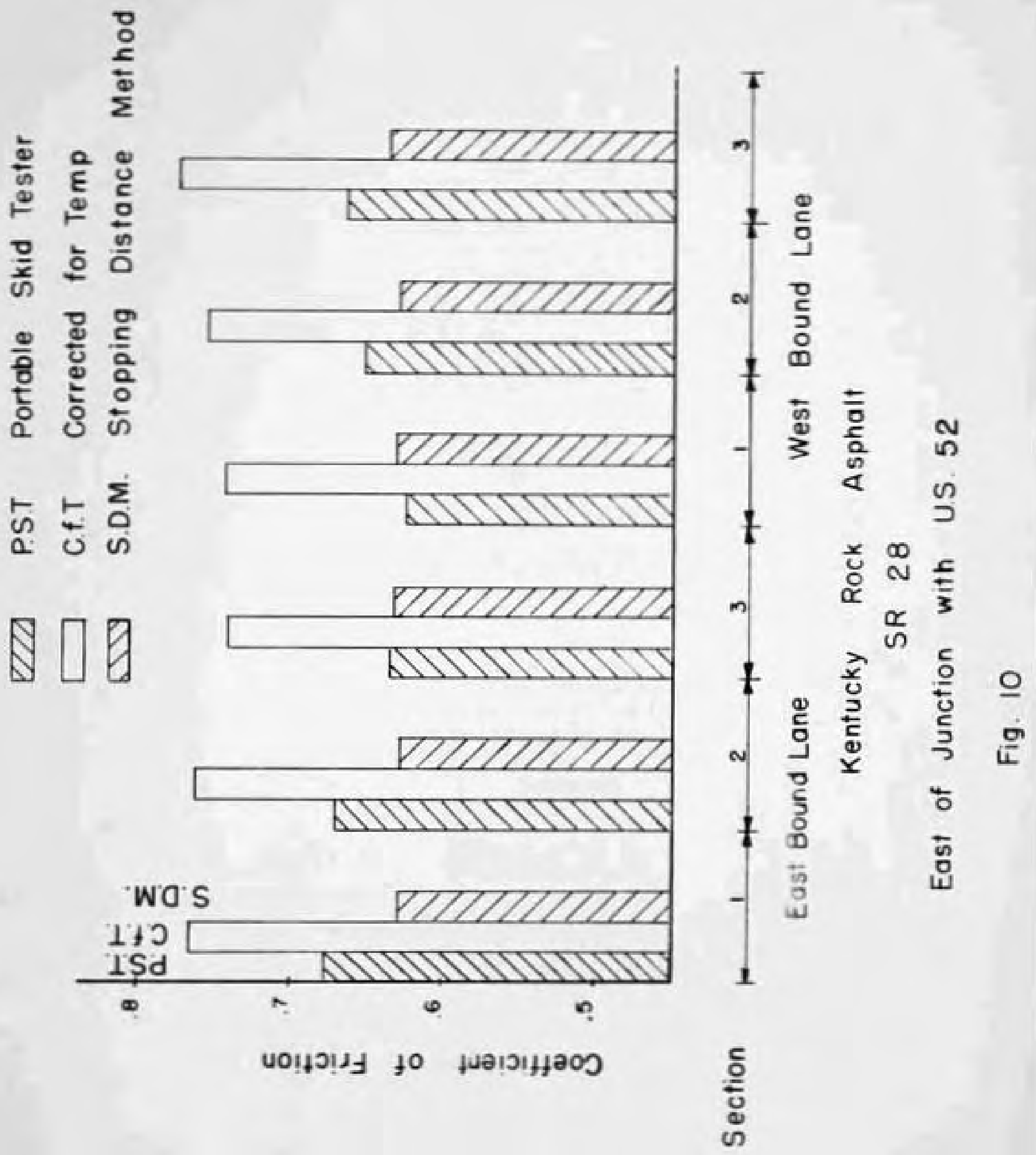




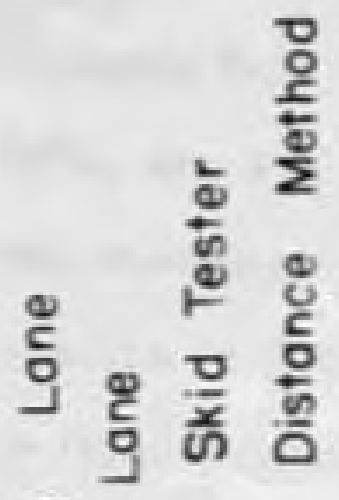

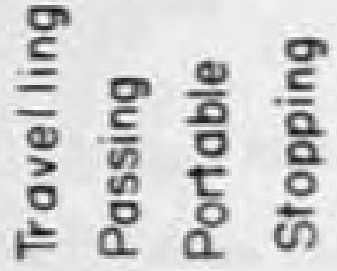

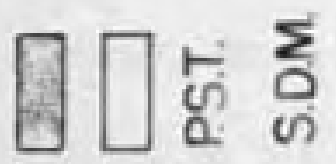

¿

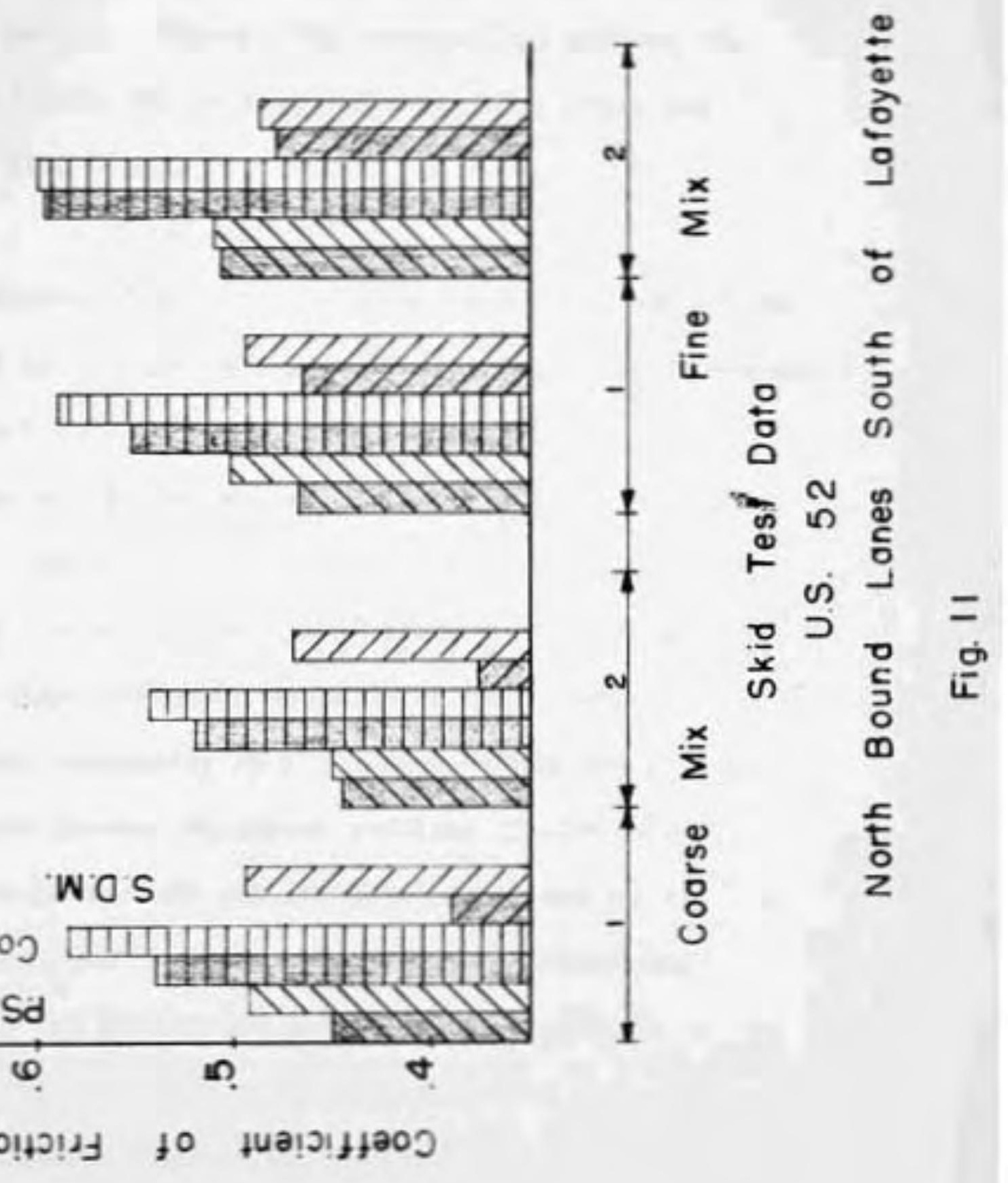




\section{Results}

The results obtained from the trafler tests are presented in tabular form in Table (2). For each aree coefficient of frietica is plotted versus the speed in Figure (1) through Figure (7).

The actual, masured values of coefficient of friction by the Portable Skld Tester, and thelr corrected values for temperature at $20^{\circ} \mathrm{C}$, are presented in Fable (3) elcng with the valnes obtained from the Stopplng Distance mothod. Figures (8) through (10) present the results of P.S.T. and S.D.M. for passing and travelleing lanes for different sections of flve arees.

\section{Conciustons}

Fran Figure (1) through Fgure (7) it is obvious that coeffleient of frlotion for almost all of the sections decresses as apeed increases. However, there could not be established a correlation between the trailer mothod and othors. A statistical analyais of variances is prosented in Appendix B which shows at ares II the values obteined by the tzaslos method are not algnifleantly dieferent within $95 \%$ of confidence 1smits for efight different eecticns in that aree. In other words the trailer, eapecising at high speed, could not detect a significant difference between different sections of ares II. Thls enalysile could not be carried out for other areas due to the lack of data. The excess heat produced st the brakes caused difocontinuance of tests by the treiler at aree I for high speeds.

Comparing the results obtained by the Portable Slcid Tester and the otoppding distance method, Figures (8) through (22) show that although the values for coefflelent of friction for each secticn are different by asch mothod, they both produce results with the samo trond. In other words, for sections on vich high values of fricticn have bean Indicated by the Portable Skid Tester the otopping distance tathod gave high velues aleo. 


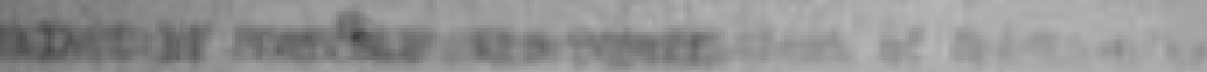

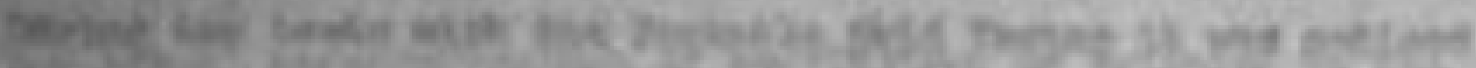

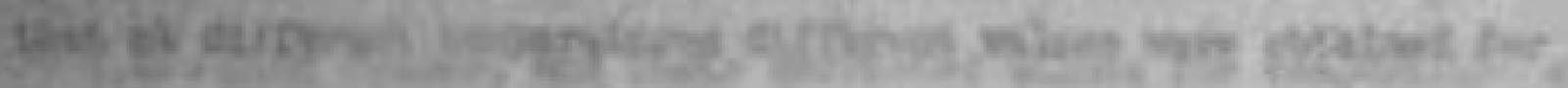

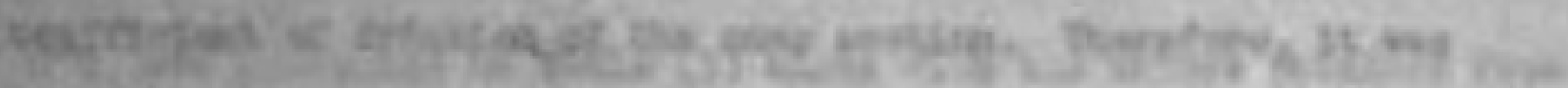

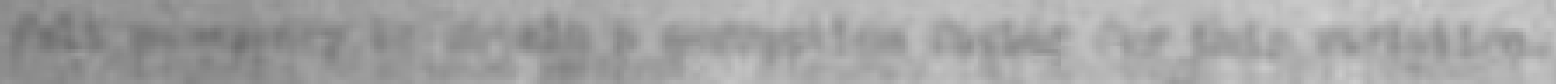

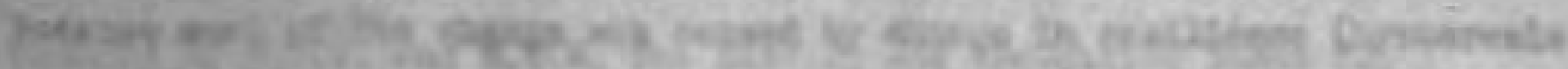

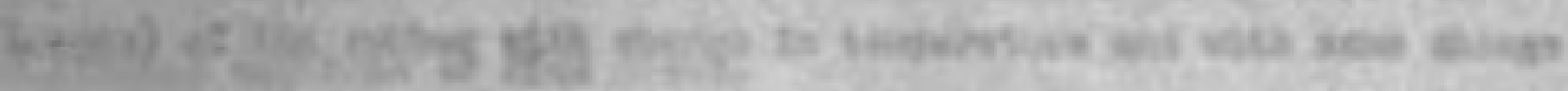

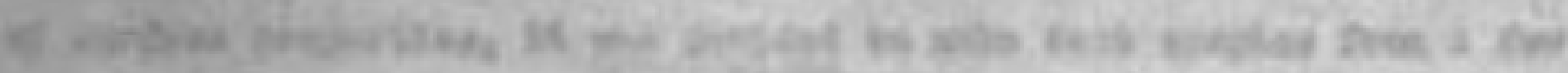

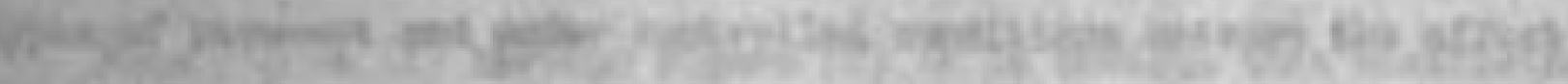

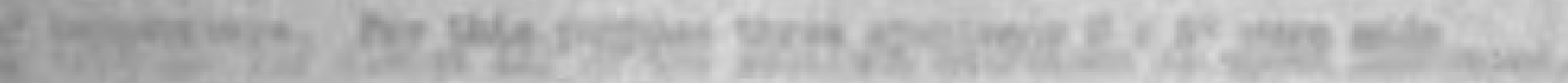

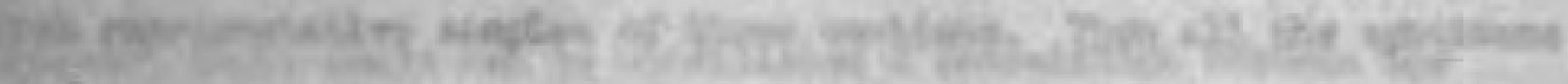

\section{APPGIDIX A}

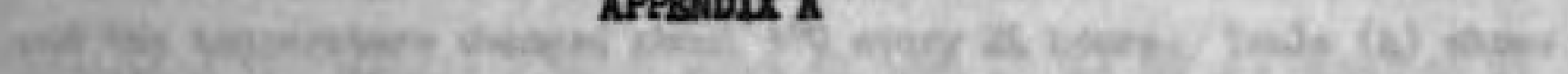

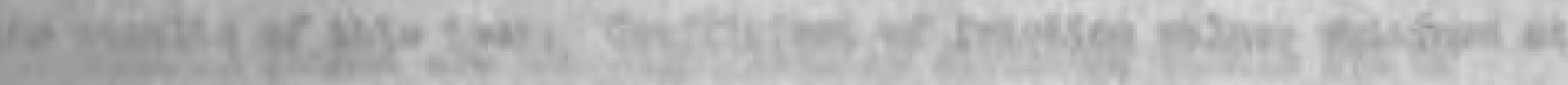

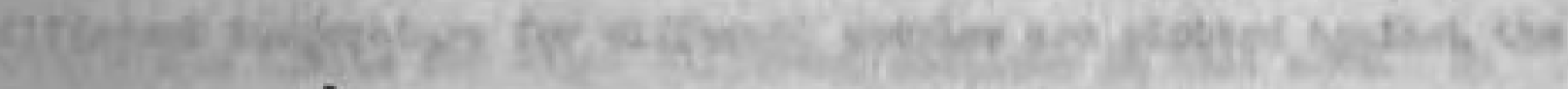
-

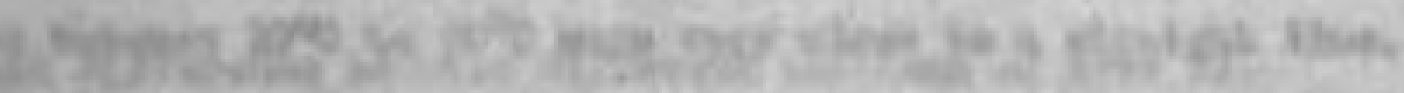

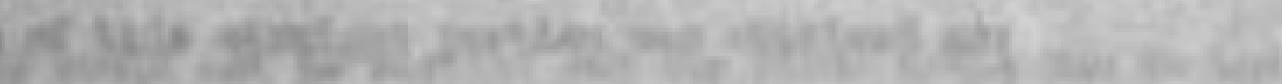

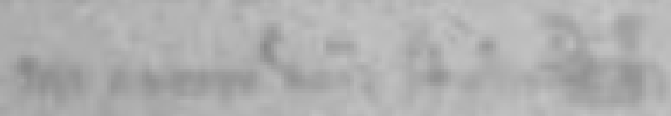

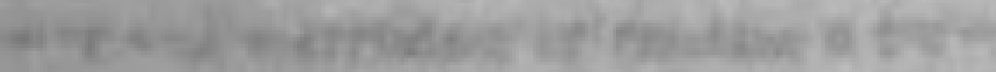

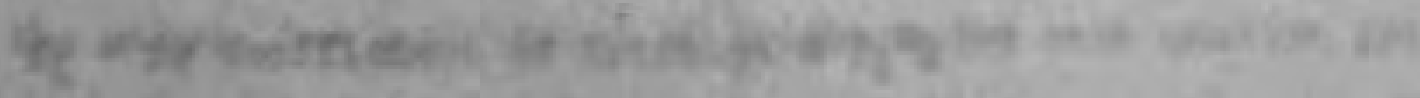




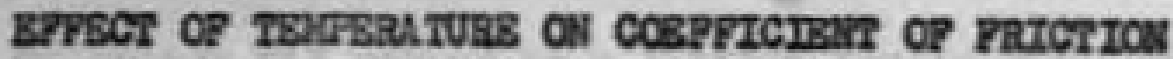

\section{OBTATISD BY PORWLALS SRTD TESTER}

During the teats with the Portable sidd Tester it was noticed that at differeat teaperatares different values were obtalned for coefriolant of frietion of the sane secticn. Therefore, it sas felt nocssaary to obtalin a correction sactor for thls varleticn. Bocause most of the change was caused by change in resilfence (hysteresis Losaos) of the rubber vith chango in teraperature and vith sene change of eurfece propertios, it was decided to make test samplos frch a fen types of pavecnent and under controlled conditions moesure the effect of tempereture. Por this purpose three specimens $8 \times 8^{n}$ were mede frot roprosentative samples of three sections. Then all the specimens and the Portable Sldd Tooter were aot in a constant tenpersture roce and tha teaperature changed about $5^{\circ} \mathrm{C}$ every $2 / 4$ hours. Table $(4)$ shours the rosults of this teat. Coeffieient of frletsicn values obtained at differunt tenperaturo for different seaples are plotted against the toeporsture in FIgure (12). It was found that all threo ourves for terperatures between $20 \% \mathrm{C}$ to $50^{\circ} \mathrm{C}$ were vary eloee to a strafight line. The oquation of this straight portlon uss obtalned es:

$$
P=x_{1}+\frac{2-2}{200}
$$

where

$$
f=1 \text { coeffielent of frietion a } \mathrm{T}^{\circ} \mathrm{C}
$$

and

$$
r_{1}=\text { is coefrielent of fritation } \theta \mathrm{r}_{1}{ }^{\circ} \mathrm{C}
$$


To ahange all values to a cortain temperature, $20 \% \mathrm{C}$ was selocted as is baso tenperetures the corrocticn fornala is thent

$$
\frac{r}{200}=s_{1}+\frac{3-20}{200}
$$

This equation was used to corroct all of the Portablo Sldd Tester Finas obtafned in the field at differout tesperstures to a cocmon temperaturv. 
Table 4

Varfatica of Coeffielent of Priotian

with Teeperature for Portable Sldd Tester

\begin{tabular}{|c|c|c|c|}
\hline Teaporature & $\begin{array}{l}\text { Sand } / 27 \\
2 / 24 \\
A\end{array}$ & $\begin{array}{c}\text { Fine Sand } \\
\text { B }\end{array}$ & 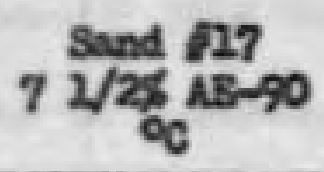 \\
\hline 42.7 & .593 & .602 & .531 \\
\hline 36.5 & .637 & .650 & .552 \\
\hline 28.5 & .652 & .670 & .570 \\
\hline 23.5 & .683 & .698 & .600 \\
\hline 17.8 & .712 & .728 & .625 \\
\hline 13.5 & .742 & $=750$ & .648 \\
\hline 6.8 & .798 & .802 & .695 \\
\hline 2.5 & 849 & .850 & .745 \\
\hline
\end{tabular}




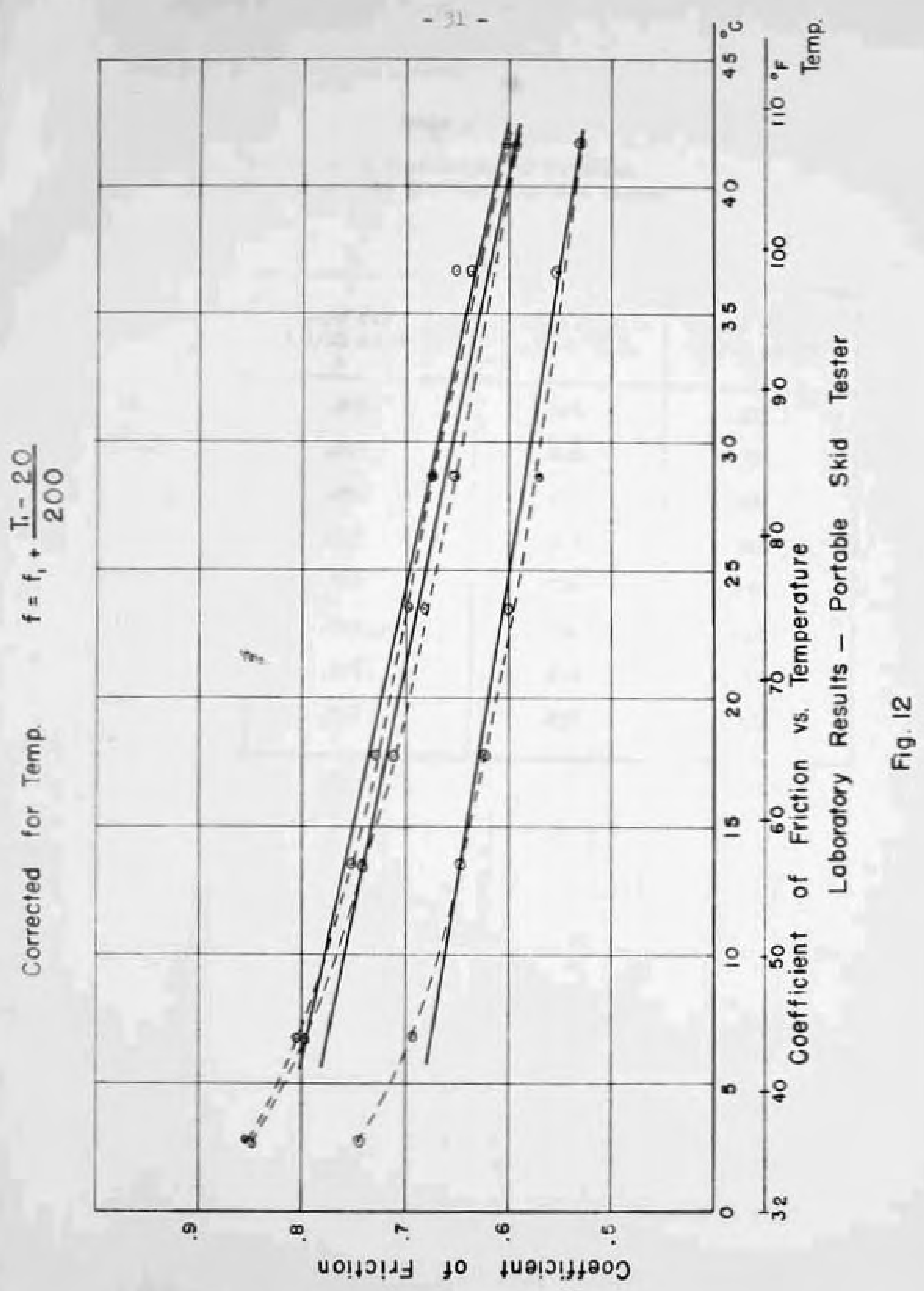


Series I Driving Lene, South Bound

\begin{tabular}{|c|c|c|c|c|c|c|c|c|c|c|c|}
\hline 00 & 1 & 2 & 3 & 4 & 5 & 6 & 7 & 8 & & & \\
\hline $\begin{array}{l}10 \\
20 \\
30 \text { and } \\
50 \\
50\end{array}$ & $\begin{array}{l}.68 \\
.66 \\
.4 .8 \\
.47 \\
.31 \\
.3 .60 \\
6.76 \\
1.372\end{array}$ & $\begin{array}{r}.69 \\
.59 \\
.40 \\
.27 \\
.13 \\
.2 .06 \\
4.326 \\
.865\end{array}$ & $\begin{array}{c}.69 \\
.53 \\
.42 \\
.32 \\
.36 \\
2.12 \\
4.494 \\
.699\end{array}$ & $\begin{array}{c}.63 \\
.53 \\
.34 \\
.25 \\
.23 \\
. .28 \\
3.534 \\
.707\end{array}$ & $\begin{array}{c}.66 \\
.48 \\
.32 \\
.30 \\
.37 \\
3.93 \\
3.725 \\
.745\end{array}$ & $\begin{array}{c}.64 \\
.48 \\
.28 \\
.26 \\
.27 \\
2.83 \\
3.3149 \\
.67\end{array}$ & $\begin{array}{c}.61 \\
.42 \\
.30 \\
.214 \\
.23 \\
2.80 \\
3.240 \\
.608\end{array}$ & $\begin{array}{c}.59 \\
.40 \\
.24 \\
.26 \\
.27 \\
.27 \\
3.76 \\
.619\end{array}$ & $\begin{array}{r}5.19 \\
4.09 \\
2.78 \\
2.37 \\
1.57 \\
16.00\end{array}$ & $\begin{array}{c}26.936 \\
16.728 \\
7.728 \\
5.617 \\
2.465 \\
256.00 \\
6.400\end{array}$ & $\begin{array}{r}3.367 \\
2.091 \\
.996 \\
.702 \\
.308\end{array}$ \\
\hline
\end{tabular}

Coivem sum of squaroa $=6.485-6.4=.085$

Blout aun of squarea $=7.434-6.4=2.034$

Total sun of squares $=7.611-6.4=1.211$

\begin{tabular}{|c|c|c|c|}
\hline Source & $c_{1}=s_{8}$ & s. 5. & B. $\mathrm{X}, \mathrm{S}$. \\
\hline $\begin{array}{l}\text { Secticne } \\
\text { Spaeda } \\
\text { Residual } \\
\text { Totel. }\end{array}$ & $\begin{array}{r}7 \\
4 \\
28 \\
39\end{array}$ & $\begin{array}{l}.085 \\
1.034 \\
2.092 \\
1.211\end{array}$ & $\begin{array}{l}.0121 \\
.2585 \\
.0033\end{array}$ \\
\hline
\end{tabular}

$$
\begin{aligned}
H_{0}: \frac{\sigma_{\theta}^{2}}{\theta} & =0 \\
7 & =\frac{.0122}{.0033}=3.67 \\
.05 & (7,28)=2.78
\end{aligned}
$$

3.67>2.78 ofenieseent

$\mathrm{H}_{0}: \frac{\sigma_{\alpha}^{2}}{\alpha}=0$

$F=\frac{.2585}{.0033}=78.33$ not significant 
Dortce III Driving Lane, North Bound

\begin{tabular}{|c|c|c|c|c|c|c|c|c|c|c|c|}
\hline $\begin{array}{l}\text { Speed } \\
\text { KFy }\end{array}$ & 1 & 2 & 3 & 4 & $5=$ & 6 & 7 & 3 & $\begin{array}{c}\text { Total } \\
B_{1}\end{array}$ & $\left(a_{1}\right)^{2}$ & \\
\hline $\begin{array}{l}10 \\
20 \\
30 \\
50 \\
\text { Fotal } \\
\left(C_{5}\right)^{2} \\
\left(c_{1}\right)_{2}\end{array}$ & $\begin{array}{r}.63 \\
.57 \\
.46 \\
.34 \\
2.02 \\
4.08\end{array}$ & $\begin{array}{r}.57 \\
.48 \\
.33 \\
.36 \\
1.59 \\
2.53\end{array}$ & $\begin{array}{r}.60 \\
.45 \\
-32 \\
.15 \\
1.52 \\
2.31\end{array}$ & $\begin{array}{r}.57 \\
.43 \\
.30 \\
.17 \\
1.47 \\
2.16\end{array}$ & $\begin{array}{r}.63 \\
.44 \\
.32 \\
.21 \\
1.60 \\
2.56\end{array}$ & $\begin{array}{r}.57 \\
.45 \\
.28 \\
.22 \\
1.52 \\
2.32\end{array}$ & $\begin{array}{c}.53 \\
.44 \\
.31 \\
.24 \\
1.52 \\
2.31\end{array}$ & $\begin{array}{l}.57 \\
.40 \\
.25 \\
.24 \\
1.46 \\
2.13\end{array}$ & $\begin{array}{c}4.67 \\
3.66 \\
2.64 \\
1.73 \\
12.7 \\
161.29\end{array}$ & $\begin{array}{l}21.81 \\
13.39 \\
6.97 \\
2.99\end{array}$ & $\left|\begin{array}{r}2.726 \\
1.674 \\
.872 \\
.374\end{array}\right|$ \\
\hline$\frac{\left(c_{1}\right)^{2}}{x}$ & 2.02 & .6225 & .5715 & .54 & .64 & .5775 & .5775 & .5257 & & & \\
\hline
\end{tabular}

Colvan sue of squares $-\sum_{j}^{c} \frac{\left(c_{j}\right)^{2}}{x}-\frac{c^{2}}{b}=5.08-5.04=.04$

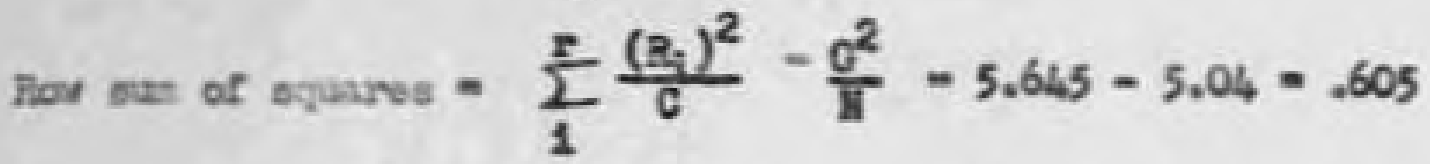

Rouflual $=0$ of equaras $=\frac{\Gamma}{i}, \frac{x^{2}}{1 j}-\frac{0}{g} \frac{\left(C_{1}\right)^{2}}{c}-\frac{\left(R_{1}\right)^{2}}{c}=\frac{C^{2}}{H}=$

tot-1 $=0$ of squarvs $=\frac{I}{i} \sum_{j}^{c} \frac{x^{2}}{1 j}-\frac{q^{2}}{N}=5.7336-5.04=.6936$

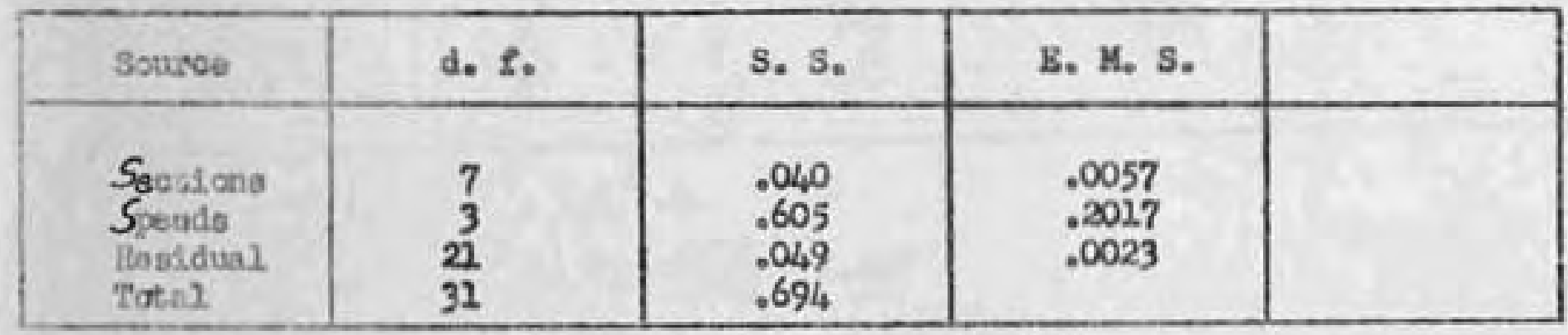

$\mathrm{H}_{0} \sigma_{s}^{2}=0$

$P=\frac{57}{27}=2.47$

$P, 05(7,22)=2.49$

$2.47<2.49 \quad$ Varlation not sigiricant

$$
\begin{aligned}
& H_{0}=\zeta_{\alpha}^{2}=0 \\
& P=\frac{.2017}{.0023}=94.34
\end{aligned}
$$

$P_{.05}(3,21)=3.07$ 
$-36=$

Sirlous IV Pesaing Lano, South Dound

\begin{tabular}{|c|c|c|c|c|c|c|c|c|c|c|}
\hline 1 & 2 & 3 & 4 & 5 & 6 & 7 & 8 & & & \\
\hline $\begin{array}{l}.65 \\
.65 \\
.55 \\
.15 \\
2.31 \\
5.326 \\
2.334\end{array}$ & $\begin{array}{r}.63 \\
.63 \\
.69 \\
.46 \\
2.22 \\
4.864 \\
1.221\end{array}$ & $\begin{array}{l}.63 \\
.63 \\
.43 \\
.39 \\
2.09 \\
4.326 \\
1.028\end{array}$ & $\begin{array}{l}.68 \\
.62 \\
.50 \\
.32 \\
2.32 \\
6.59 \\
1.123\end{array}$ & $\begin{array}{l}.70 \\
.65 \\
.54 \\
.39 \\
2.28 \\
5.298 \\
1.299\end{array}$ & $\begin{array}{r}.65 \\
.61 \\
.42 \\
.30 \\
2.98 \\
3.920 \\
.960\end{array}$ & $\begin{array}{l}.68 \\
.66 \\
.42 \\
.42 \\
2.17 \\
4.709 \\
2.177\end{array}$ & $\begin{array}{l}.64 \\
.66 \\
.43 \\
.30 \\
2.03 \\
4.121 \\
2.030\end{array}$ & $\begin{array}{c}5.26 \\
5.21 \\
3.78 \\
3.03 \\
17.18 \\
295.152 \\
9.229\end{array}$ & $\begin{array}{r}27.666 \\
26.1122 \\
14.288 \\
9.181 \\
\frac{g^{2}}{4}=9.2\end{array}$ & $\begin{array}{l}3.458 \\
3.266 \\
1.786 \\
2.248\end{array}$ \\
\hline
\end{tabular}

Colum rua of aquares $=9.24 .5-9.223=.022$

Bort vin of squn ras $=9.656-9.223=0.433$

Telal $=$ of of suares $=9.744-9.223=0.491$

\begin{tabular}{|c|c|c|c|}
\hline Souroo & d. $t$. & 3. S. & B. H. S. \\
\hline $\begin{array}{l}\text { Seotlana } \\
\text { Spooda } \\
\text { Residian } \\
\text { Total }\end{array}$ & $\begin{array}{r}7 \\
3 \\
22 \\
31\end{array}$ & $\begin{array}{l}.022 \\
.433 \\
.058 \\
.491\end{array}$ & $\begin{array}{l}.0031 \\
.0443 \\
.0028\end{array}$ \\
\hline
\end{tabular}

$$
\begin{aligned}
& G_{\alpha x}^{2}=0 \\
& P=05(7,21)=2.49 \quad 1.307<2.49 \text { not significant } \\
& \mathbb{P}=\frac{.1 .43}{.0026}=51.53 \quad 51.53>3.07 \text { as gnifleant }
\end{aligned}
$$

